\title{
Foregrounding the Background: Images of Dutch and Flemish Household Servants
}

\author{
Diane Wolfthal
}

To a great extent, art historians who study early modern women have focused on what Patricia Skinner has termed "the great and the good": aristocratic women, wives of wealthy merchants, and female artists, saints, and nuns. ${ }^{1}$ Not only do publications privilege these groups, but so do titles of paintings that were invented in the modern era. Such titles as Lady at her Toilette, Young Woman with a Pearl Necklace, or Man Visiting a Woman Washing her Hands disregard the presence of the working-class women in the compositions (Figs. 7.1-7.2). ${ }^{2}$

This essay instead explores a group that art historians have largely ignored: ordinary female household servants. Although several historians have focused on seventeenth-century Dutch servants, few art historians have discussed them, and, other than Bert Watteeuw's recent essay on Rubens' domestic staff, household workers from the Southern Netherlands or from earlier centuries have been largely overlooked. ${ }^{3}$ The reasons for this are numerous. Few documents

1 Patricia Skinner's phrase derives from her paper, "The medieval female life cycle as an organizing strategy," presented at "Gender and Medieval Studies Annual Conference: Gender, Time and Memory," Swansea University, 6 January 2011-8 January 2011. I would like to thank Amanda Pipkin and Sarah Moran for inviting me to speak at the conference Concerning Early Modern Women of the Low Countries and for their helpful bibliographical suggestions and thoughtful comments and on earlier drafts of this essay.

2 See, among others, Otto Nauman, "Frans van Mieris's Personal Style," in Frans van Mieris 16351681, ed. Quentin Buvelot (The Hague: Royal Picture Gallery Mauritshuis, 2006), 37, fig. 13; Peter van der Ploeg, "A Woman Before a Mirror," in Frans van Mieris 1635-1681, ed. Quentin Buvelot (The Hague: Royal Picture Gallery Mauritshuis, 2006), 159, fig. 31b; Peter C. Sutton, Lisa Vergara, and Ann Jensen Adams, Love Letters: Dutch Genre Paintings in the Age of Vermeer (London: Frances Lincon, 2003), 164-65, figs. 1-2.

3 Historical studies include Marybeth Carlson, "Domestic Service in a Changing City Economy: Rotterdam, 1680-1780," Ph. D. dissertation, University of Wisconsin-Madison, 1993; Carlson, "A Trojan Horse of Worldliness? Maidservants in the Burgher Household in Rotterdam at the End of the Seventeenth Century," in Women of the Golden Age: An International Debate on Women in Seventeenth-Century Holland, England, and Italy, ed. Els Kloek, Nicole Teeuwen, and Marijke Huisman (Hilversum: Verloren, 1994). 87-101; Carlson, "There is no Service Here but my Service!': Municipal Attempts to Regulate Domestic Servant Behavior in Early Modern Holland." in Power and the City in the Netherlandic World, ed. Wayne te Brake and 


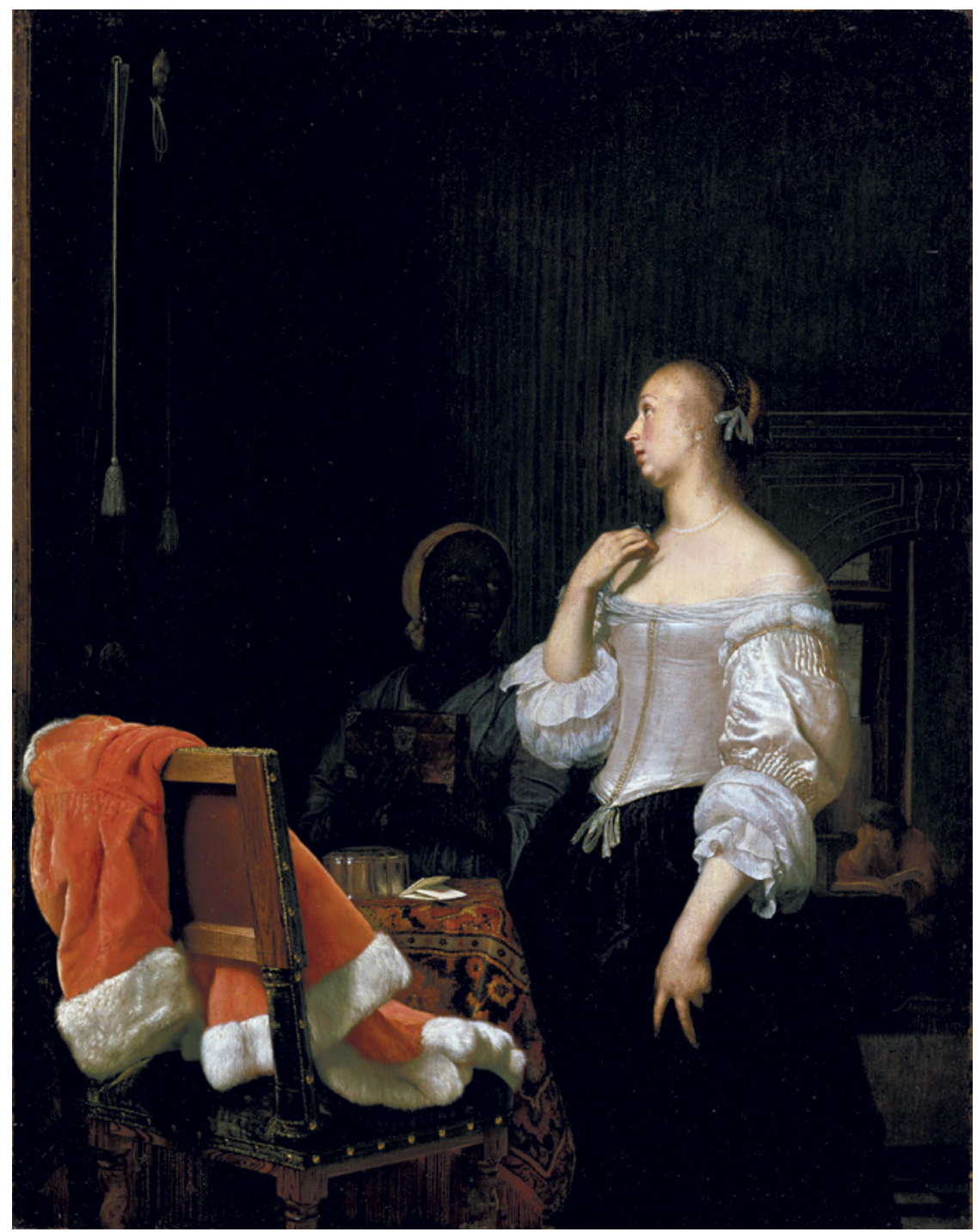

FIGURE 7.1 Frans van Mieris the Elder, Young Women with a Pearl Necklace, c. 1664, Staatliche Museen zu Berlin, Gemäldegalerie

Wim Klooster (Leiden and Boston: Brill, 2006), 225-234; Rudolf Dekker, "Maid Servants in the Dutch Republic: Sources and Comparative Perspectives. A Response to Marybeth Carlson," in Women of the Golden Age, 97-101; and Derek Phillips, Well-Being in Amsterdam's Golden Age (Amsterdam: Pallas Publications, 2008), 79-93, which is largely dependent on Carlson. See Bert Watteeuw, "Household Names? Domestic Staff in Rubens's Home," in Rubens in Private: The Master Portrays his Family, ed. Ben van Beneden (London: Thames \& Hudson, 2015), 55-75. In this volume, see also Sarah Joan Moran, "Resurrecting the 'Spiritual Daughters': 


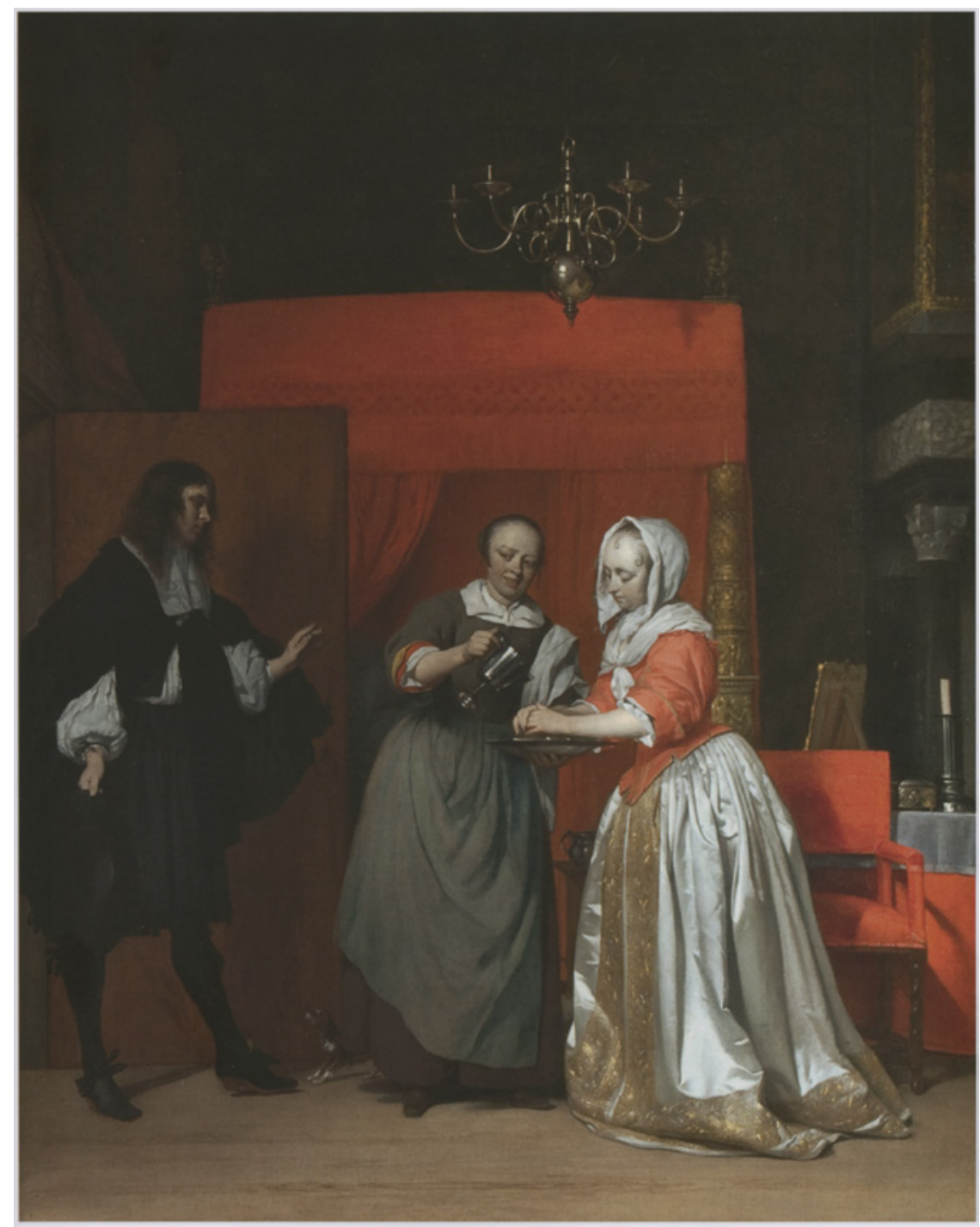

FIGURE 7.2 Gabriel Metsu, A Man Visiting a Woman Washing her Hands, c. 1664-62, private collection

link art and servants. Domestic workers rarely produced art and the art that they owned cannot be identified today. ${ }^{4}$ Furthermore, when such women are

The Houtappel Chapel and Women's Patronage of Jesuit Building Programs in the Spanish Netherlands," 276-278.

4 For art owned by servants, see Watteeuw, "Household names," 68, and below for a painting of Geertje Dircx. 


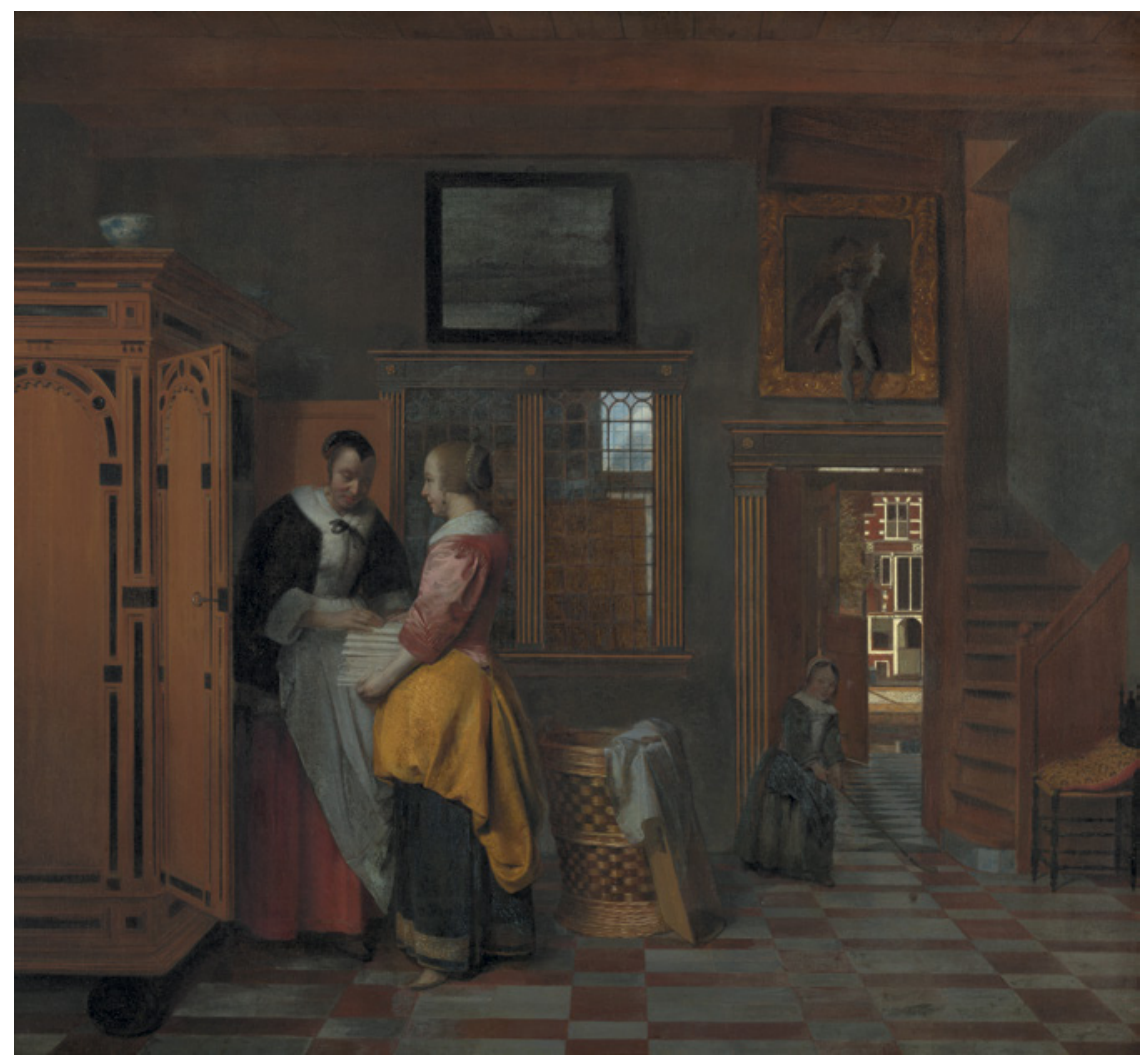

FIGURE 7.3 Pieter de Hooch, Interior with Women beside a Linen Cupboard, 1663, Rijksmuseum, Amsterdam

depicted, they can seldom be linked with certainty to either a name or occupation. ${ }^{5}$ It is often difficult, for example, to distinguish housewives from hired help. The figures in the middle ground of Rogier van der Weyden's paintings who wash laundry or carry parcels could be housewives or servants. ${ }^{6}$ Similarly, in Pieter de Hooch's painting of two women storing linen in a cupboard, Wayne Franits identifies the figure on the right as the mistress and her companion as the maid, whereas John Loughman argues the reverse (Fig. $7 \cdot 3) .^{7}$ Since employ-

5 Diane Wolfthal, "Household Help: Early Modern Portraits of Female Servants," Early Modern Women: An Interdisciplinary Journal 8 (2013): $5^{-52}$.

6 See Diane Wolfthal and Cathy Metzger, Corpus of Early Netherlandish Painting 22. Los Angeles Museums (Brussels: Royal Institute of Cultural Heritage, 2014), 157, fig. 16, and a figure carrying a parcel in the background of Rogier's Magdalen Reading, London, National Gallery.

7 Wayne E. Franits, Paragons of Virtue: Women and Domesticity in Seventeenth-Century Dutch Art (Cambridge: Cambridge University Press, 1993), 104. Yet in a painting in the National 
ers often gave their household help their cast-off clothes, costume alone is an unreliable indicator of class.

But art historians have ignored servants for another reason: the artists themselves often marginalize them. In fifteenth-century Netherlandish art, servants are shown off to the side, partially cut off by the frame or other figures, situated in the background, or seen from the back. ${ }^{8}$ Sometimes architectural elements overlap them, obliterating their facial features, and thereby depriving them of their individuality, as in illuminations of a servant carrying bath water through an entryway (Fig. 7.4). ${ }^{9}$ Sometimes color or size differentiates maid from mistress. In a late thirteenth-century miniature, the taller figure, Judith, wears red and blue, her shorter maid, dull grey (Fig. 7.5). ${ }^{10}$ Dutch Golden Age painters adopt similar strategies. In one painting Gabriel Metsu shows the lady of the house in rich colors, shimmering satins, and luminous light, all of which brings our eye to her (Fig. 7.2). ${ }^{11}$ Her servant, by contrast, wears plainer, coarser, and darker clothing. In a second painting by Metsu, the servant stands to the side and in the background; in a third she is a shadowy figure, off to the side, cut off by a table, hidden in darkness. ${ }^{12}$ In Bartolomeus van der Helst's group portrait, the three servers are not only pushed to the middle ground, off to the side, and even partially out the door, but they also seem paler, almost ghostlike in appearance (Fig. 7.6).

But there is a final reason why art historians so often overlook servants: our discipline is closely tied to the art market and to wealthy donors, and as a

Gallery, London, dated to the same years, the wealthy Adriana van Heusden wears both an apron and a similar expensive fur-trimmed black jacket. John Loughman, "Between Reality and Artful Fiction: The Representation of the Domestic Interior in SeventeenthCentury Dutch Art," in Imagined Interiors: Representing the Domestic Interior Since the Renaissance, ed. Jeremy Aynsley and Charlotte Grant (London: Victoria and Albert Museum, 2006), 73 .

8 See, for example, Master of the Ghent Privileges, "Presentation in the Temple," Book of Hours, New York, Morgan Library and Museum, Ms. M. 82, fol. 66r; Limbourg Brothers, "Exaltation of the Cross," Très Riches Heures, Chantilly, Musée Condé, fol. 143r; Master of the Walters 281, "Flight into Egypt," Malet-Lannoy Hours, Walters Art Museum, Ms. 182, fol. 103 .

9 See, for example, Millard Meiss, French Painting in the Time of Jean de Berry. The Late Fourteenth Century and the Patronage of the Duke (London: Phaidon Press, 1967), vol. 2, figs. $322-323$.

10 Getty Museum, Ms. Ludwig 18, Maquette Bible, Franco-Flemish, ca. 1270. Donated by Philip, Duke of Burgundy, to the Cistercian convent at Marquette.

11 Loughman, "Between Reality and Artful Fiction," 94.

12 For these paintings, see Wayne E. Franits, "Gabriel Metsu and the Art of Luxury," 54, 67 in Gabriel Metsu, ed. Adriaan E. Waiboer (New Haven and London: Yale University Press, 2010). 


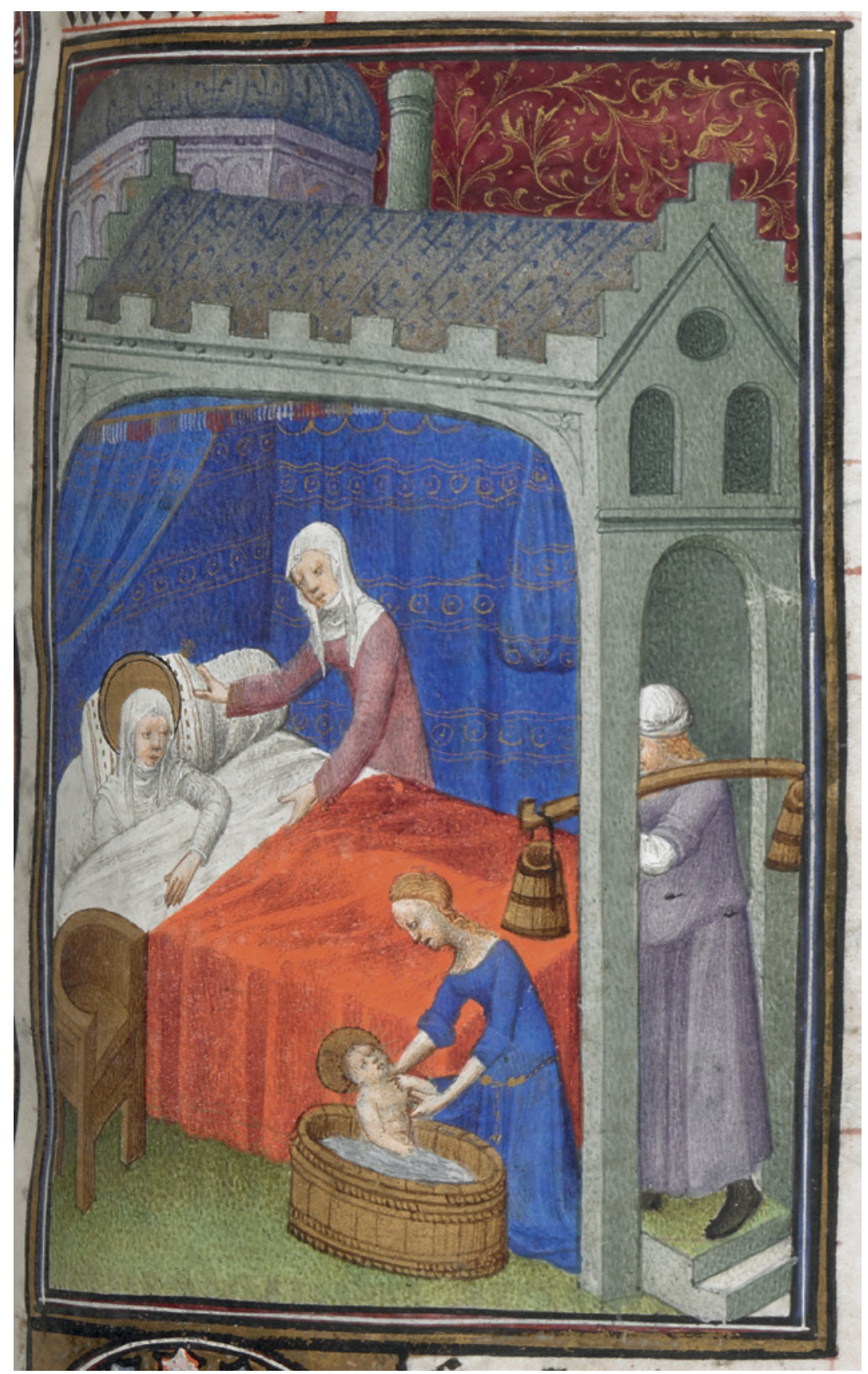

FIGURE 7.4 Egerton Workshop, Birth of the Virgin, from the Breviary of John the Fearless and Margaret of Bavaria, c. 1410-1419, Harley 2897, fol. 385, British Library, London 


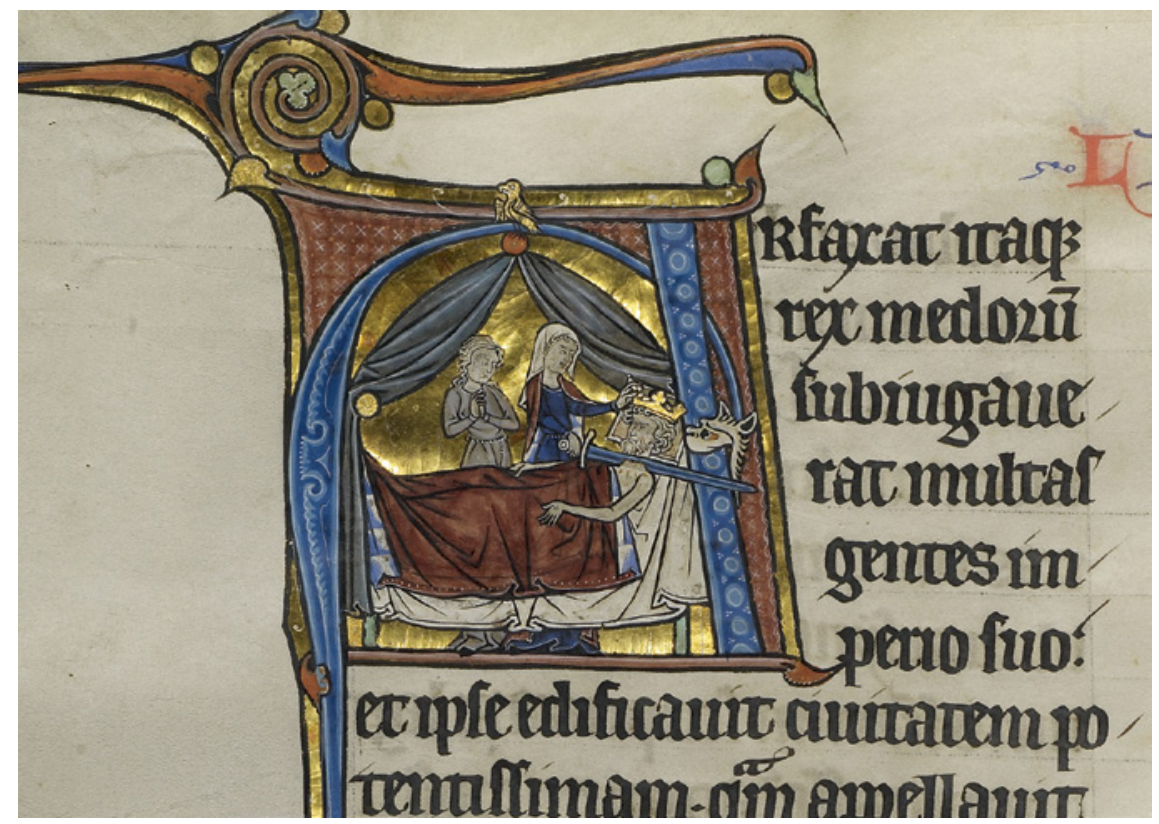

FIGURE 7.5 Unknown artist (probably from Lille), Judith Beheading Holofernes, from the Marquette Bible, c. 1270, Ms. Ludwig 18, v. 3, fol. 241v, J. Paul Getty Museum, Los Angeles

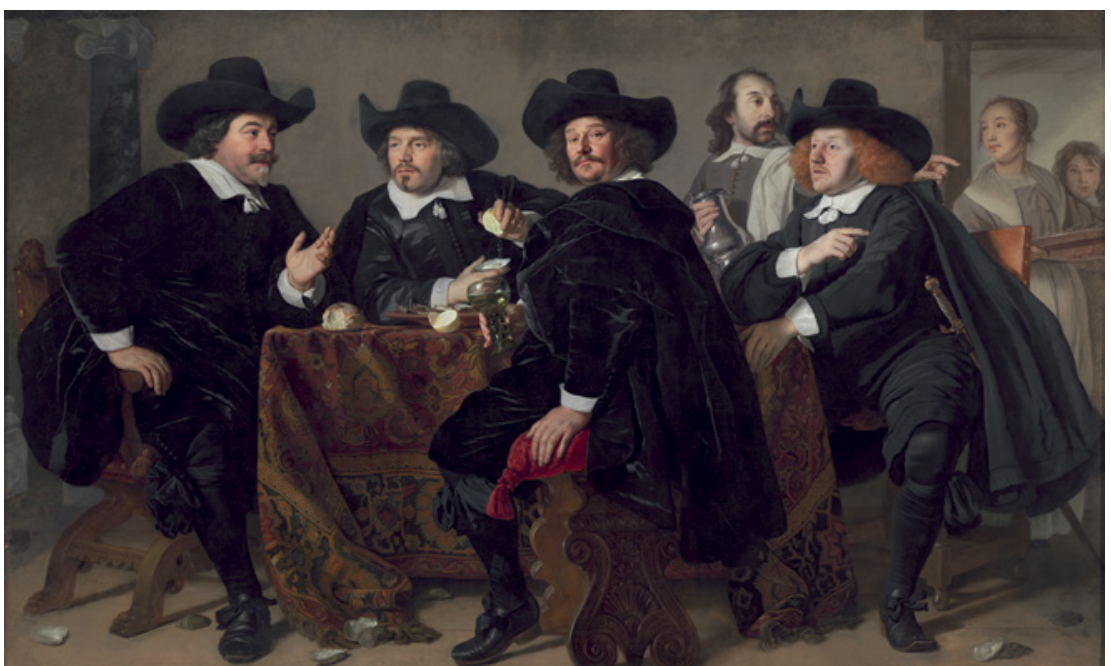

FIGURE 7.6 Bartholomeus van der Helst, The Governers of the Kloveniersdoelen, 1655, Amsterdam Museum, Amsterdam 
result has long identified with the elite. For example, Ruth Mellinkoff, in her fine book Outcasts, asserted, "While we who live in the era of the common man publicly extol his virtues, privately we admire and covet the attributes of the upper class ... [F] ew would not be delighted to have a titled guest at table, no matter how tarnished the title might be." ${ }^{\prime 9}$ And Donald Kuspit astutely observed, "the irrational exuberance of the contemporary art market is about the breeding of money, not the fertility of art ... Only art that makes money finds its way into the textbooks, which sometimes seem like rationalizations of auction results." ${ }^{13}$

Past scholarship on images of servants has focused primarily on Dutch Golden Age genre paintings and prints. In 1988, Simon Schama explored the association between cleanliness and the Dutch nation, seeing the Dutch home as a microcosm of the republic. ${ }^{14} \mathrm{He}$ also demonstrated how imagery emphasized the mistress's responsibility to control her servants' lust, sloth, gluttony, and greed. ${ }^{15}$ In 1993, Wayne Franits examined Dutch genre paintings that show the ideal: a mistress properly supervising her servant so as to insure the smooth functioning of the home. ${ }^{16}$ The next year Martha Hollander analyzed six comedic paintings by Nicolaes Maes that explore tensions between maids and mistresses in spatially divided and morally disordered domestic interiors. ${ }^{17}$ In 2001, Malgorzata Sarnowiec studied the illustrations in two books, which were printed in Amsterdam in 1682, that portrayed servants as lustful, lazy, gossiping harpies and thieves. ${ }^{18}$

13 Donald Kuspit, "Art Values or Money Values?" artnet, Dec. 22, 2007. http://www.artnet .com/magazineus/features/kuspit/kuspit3-6-07.asp, Accessed 2/24/17. See also, among many others, Michael Kimmelman, "Art, Money, and Power," The New York Times, May 11, 2005 http://www.nytimes.com/2005/05/11/arts/design/art-money-and-power.html?_r=0, accessed $4 / 8 / 17$.

14 Simon Schama, The Embarrassment of Riches: An Interpretation of Dutch Culture in the Golden Age (Berkeley: University of London Press, 1988), 378-82.

15 Ibid., 393, 457-58.

16 Franits, Paragons of Virtue, 100-110.

17 Martha Hollander, "The Divided Household of Nicolaes Maes," Word and Image 10.2 (April-June 1994): 138-155.

18 Malgorzata Sarnowiec, "De zeven zonden van het dienstmeisje: Een moralistische en libertijnse versie beschreven en verbeeld," in 'Tweelinge eener dragt': Woord en beeld in de Nederlanden (1500-1750), ed. Karel Bostoen, Elmer Kolfin, and Paul J. Smith (Hilversum: Verloren, 2001), 199-224. Servants are also discussed in passing in Sutton, Vergara, and Jenson Adams, Love Letters. Christine Petra Sellin explored servants through the biblical story of Hagar. See Fractured Families and Rebel Maidservants: The Biblical Hagar in Seventeenth-Century Dutch Art and Literature (New York and London: T \& T Clark International, 2006). 
This essay, by contrast, will also examine Flemish and earlier works, and will, on occasion, compare them to images produced outside the Netherlands. In addition, I will interrogate a broader range of sources, not only genre paintings and prints, but also artists' biographies, portraits, and doll houses in order to enrich our understanding of female servants in the early modern Low Countries. If artists repeatedly relegated servants to the background, I propose to do the reverse: to foreground these figures.

The term "servant" is a broad category that in early modern times encompassed a wide spectrum from menial maids who cleaned the house to court artists and aristocratic ladies-in-waiting. ${ }^{19}$ Servitude was a deeply engrained concept: even lovers served their beloved, and rulers their God. ${ }^{20}$ This essay, however, only concerns household workers who performed such tasks as sweeping floors, serving food, scrubbing pots and pans, starching and ironing laundry, and caring for young children. In doing so, I will ask: What was the relationship of artists to their servants? How have art historians discussed household workers? Do portraits of ordinary servants survive? How are hierarchical differences among servants visualized? What does material culture reveal about the lived experience of servants and how they were viewed by their masters? What can be learned by broadening our scope to include art produced outside the Netherlands and over several centuries? And finally, how do images of servants challenge our thinking about race, class, and gender?

Artists' Servants

One way to better understand the intersection of art history and servants is to study artists' relationships with their household help. But documents generally offer only a fleeting glimpse of the lives of artists' servants. ${ }^{21}$ In this section, however, I will focus on two cases for which numerous documents survive, the painters Rembrandt and Maria van Oosterwijk, who treated their servants in

19 For a thoughtful analysis of the term "domestic work," see Mark Hailwood, "How 'Domestic' was Women's Work?” https:/earlymodernwomenswork.wordpress.com/2016/o6/og/ how-domestic-was-womens-work/.

20 P. J. P. Goldberg, "What Was a Servant," in Concepts and Patterns of Service, ed. by Anne Curry (London: Boydell Press, 200o), 2.

21 For example, to settle a dispute between Judith Leyster and the mother of a former pupil, the painter promised that her servant would return his belongings. Other than that incident nothing is known about this servant. See Ellen Broersen, “Judita Leystar': A Painter of 'Godd, Keen Sense', in James A. Welu and Peter Biesboer, Judith Leyster: A Dutch Master and Her World (Worcester: Worcester Art Museum, 1993), 20. I am grateful to Frima Fox Hofrichter for this reference. 
diametrically opposite ways. After Rembrandt's wife Saskia Uylenburgh died in 1642, he hired a widow, Geertje Dircx, to care for his nine-month old son Titus. Soon Rembrandt and Geertje became sexually involved and lived as husband and wife for several years. We know this not simply from Geertje's testimony, but also from the writings of Arnold Houbraken, who based his knowledge on information from his master Samuel van Hoogstraten, Rembrandt's pupil in the 1640 s. Houbraken related, "Rembrandt had as Wife a little farm woman from Raarep, or Ransdorp in Waterland, rather small of person, but well made in appearance, and plump of body."22

In 1647, Rembrandt hired Hendrickje Stoffels as a live-in servant, and soon she replaced Geertje in his affections. In 1654, Hendrickje was called before the Reformed Church Council to face the accusation of "having committed whoredom with Rembrandt the painter."23 Pregnant with their daughter Cornelia, she was banned from communion and asked to do penance. Although some artists married their servants, Rembrandt was unwilling to wed Hendrijke at least in part because he would lose an inheritance from Saskia if he did so. ${ }^{24}$ Nevertheless, Hendrijcke remained with him until her death in 1663 .

Geertje paid a steeper price for her relationship with Rembrandt. ${ }^{25} \mathrm{He}$ attempted to appease his former lover with an offer of a small alimony, which she rebuffed. Soon the relationship became acrimonious. Geertje sued the painter for breech of promise, and the court ruled that Rembrandt should pay

22 For the translation, see Bob Haak, Rembrandt: His Life, His Work, His Time, trans. Elizabeth Willems-Treeman (New York: Harry N. Abrams, 1969), 216. The original language is from Arnold Houbraken, De groote schouburgh der Nederlantsche konstschilders en schilderessen, ed. P. T. A. Swillens, part I (Maastricht: Leiter-Nypels, 1943), 214: "Hij had ten Huisvrouw een Boerinnetje van Raarep, of Ransdorp in Waterlant, wat klein van persoon maar welgemaakt van wezen, en poezel van lichaam."

23 Mariët Westermann, Rembrandt (London: Phaidon, 2000), 237. The full quote is "Hendrickie Jaghers voer de vergadering verschenen zijnde, bekent dat se met Rembrant de schilder Hoererije heeft gepleecht, is daerover ernstelijck bestraft, tot boervardicheijt vermaent en van den taffel des Herren afgehouden," for which see Rembrandt's Women, ed. by Julia Lloyd Williams (New York: Prestell, 2001), 259, note 11.

24 When the Antwerp painter Pieter van Lint was widowed after thirty-five years of marriage, he wed his servant Anna Moren, with whom he had three sons." Lint, Peter Van," Benezit Dictionary of Artists. Oxford Art Online. Oxford University Press, accessed October 15, 2016, http://www.oxfordartonline.com.ezproxy.rice.edu/subscriber/article/benezit/Boo110194.

25 For the documents relating to Geertje Dircx, see C. Hofstede de Groot, Die Urkunden über Rembrandt (1575-1721) (The Hague: Marinut Nijhoff, 1906), 130-52, 186-87, nos. 113, $117-18,120-23,165$. For this episode, see also H. F. Wijnman, "Een episode uit het Leven van Rembrandt; De Geschiedenis van Geertje Dircks," Jaarboek van het Genootschap Amstelodamum 60 (1968): 103-18; S. A. C. Dudok van Heel, "Rembrandt: His Life, his Wife, the Nursemaid and the Servant," 19, 24; 161 (cat. no. 78); 220 (cat. no. 126) in Rembrandt's Women; Simon Schama, Rembrandt's Eyes (New York: Alfred A. Knopf, 1999), 544-59. 
her two hundred guilders a year for the rest of her life, and that she should leave the jewelry that Rembrandt had given her to his son Titus upon her death. When she later pawned some of this jewelry, which had been Saskia's, Rembrandt had her committed to a Spinning House, that is, a women's workhouse. Friends tried to have her released, but Rembrandt fought to keep her incarcerated and threatened one of her supporters by shaking his finger at her and warning that if she tried to gain Geertje's freedom, she would regret it. Despite letters of protest from Rembrandt, Geertje was released after five years, but died soon afterwards.

This narrative reads like contemporary popular literature, which often portrays servants who try to manipulate the widowers for whom they work. For example, an anonymous tract of 1682, titled Zeven duivelen, regerend de hedendaagsche dienstmaagden (The Seven Devils Ruling Maidens Nowadays), asserts, "No one has more trouble with maidservants than widowers." 26 According to this book, servants coddle widowers, wear seductive clothing, and get their masters drunk, all in the hopes of marrying them. After marriage, they embezzle the families' assets. Reinforcing these words are images, such as one of a thieving maid stealing from a pantry while turning her head to see if she is being observed. ${ }^{27}$ Such texts and images undoubtedly influenced the outcomes of court cases like Geertje's.

But class prejudices are not confined to the past. In a publication of 1984 , one author asserts that Hendrijcke's "simpler background may not have given her the art of conversation." ${ }^{28}$ Similarly, in 2001, another author asked, "Were Rembrandt's reduced circumstances due to Geertje Dircks? One clue is that she had appropriated an expensive rose-cut diamond ring."29 The use of the word "appropriated" flattens the complexities of the situation, and Mariët Westermann offered a more just interpretation when she concluded that "Rembrandt's affairs can hardly be held responsible for his financial woes." ${ }^{30}$

Maria van Oosterwijk, a specialist in flower painting, had a very different relationship with her servant Geertje Pieters, who was probably a distant

26 Anonymous, Zeven duivelen, regerend de hedendaagsche dienstmaagden (1682), quoted by Carlson, "Domestic Service in a Changing City Economy," 199. For the legal regulation of servants, see Carlson, “'There is No Service Here but my Service," 225-34. See Sarnowiec, "De zeven zonden van het dienstmeisje." For legal cases involving servants, see G. M. E. Dorren, Eenheid en verscheidenheid. De burgers van Haarlem in de Gouden Eeuw (Amsterdam: Prometheus), 61-64.

28 Christopher White, Rembrandt (London: Thames and Hudson, 1984), 129.

29 Van Heel Dudok, "Rembrandt: His Life, his Wife, the Nursemaid and the Servant," 24.

3o Westermann, Rembrandt, 237 . 
relative. ${ }^{31}$ Termed a "dienstmagt" in Houbraken's biography, Pieters' role is confirmed by the activities that he ascribes to her, such as preparing van Oosterwijk's paints and retrieving her coat from a neighbor. ${ }^{32}$ Mistress and maid together visited Constantijn Huygens, who wrote a poem that confirms that Pieters was the painter's servant. ${ }^{33}$ Van Oosterwijk taught Pieters to paint, and eventually she became an artist in her own right. ${ }^{34} \mathrm{~A}$ flower painting, dated around 1675 and produced in a style that is very close to Van Oosterwijk's, is signed "Gerti Pietersz." ${ }^{35}$ Further proof of her output lies in an inventory, dated 1681, of a collection in The Hague, which attributes a painting to her. Both Maria van Oosterwijk and her brother bequeathed Pieters one hundred guilders, and after her mistress's death Pieters lived independently, supporting herself as a painter. ${ }^{36}$

$31 \quad$ Employers often hired relatives as servants. See Raffaelli Sarti, "Who are Servants? Defining Domestic Service in Western Europe (16th-21st Centuries)," in Proceedings of the 'Servant Project,' ed. S. Pasleau and I. Schopp with R. Sarti (Liège: I'Université de Liège, 2006), 4. Pieters was granddaughter of the art collector Melchior Wyntges. For her, see http://resources.huygens.knaw.nl/bwn1780-1830/DVN/lemmata/data/wyntges (accessed on Dec. 8, 2014), and A. Bredius, "Archiefsprokkelingen. Een en ander over Maria van Oosterwijk, 'vermaert konstschilderesse," Oud Holland $5^{2}$ (1935): 180-182. For Arnold Houbraken's biography, see De groote schouburgh der Nederlantsche konstschilders en schilderessen, ed. P. T. A. Swillens, part II (Maastricht: Leiter-Nypels, 1944), 170-171. For a translation of it, see Julia K. Dabbs, Life Stories of Women Artists, 1550-1800. Anthropology (Farnham and Burlington: Ashgate, 2009), 16.

32 Houbraken, De groote schouburgh, part II, 170-71.

33 De Gedichten van Constantijn Huygens, ed. by J. A. Worp (Groningen: J. B. Wolters, 1898), vol. 8, 137. The poem is titled "Met een silver palet geschonken aen Geertje Pieters dienstmaeght, schildersche."

34 Similar cases occurred in Spain. See Maria de los Santos García Felguera, La Fortuna de Murillo (1682-19oo) (Seville: EXcma, Diputacion Provincial de Sevilla, 1989), 174-75 (I am grateful to Carmen Fracchia for this reference); Jennifer Montagu, "Velázquez Marginalia: His Slave Juan de Pareja and his Illegitimate Son Antonio," Burlington Magazine 125 no. 968 (Nov. 1983): 683-84; Antonio Palomino, Lives of the Eminent Spanish Painters and Sculptors, trans. Nina Ayala Mallory (New York: Cambridge University Press, 1987), 208; Antonio Palomino de Castro y Velasco, Las Vidas de los pintores y estatuarios eminentes españoles (London: Samuel Baker and T. Payne, 1744), 102.

35 Marianne Berardi, "Oosterwijk, Maria van," in Concise Dictionary of Women Artists, ed. Delia Gazie (New York: Routledge, 1997), vol. 2, 1043-1044; Horst Gerson, Catalogue of Paintings in the Fitzwilliam Museum, Cambridge 1. Dutch and Flemish Schools (Cambridge: Syndics of the Fitzwilliam Museum, 1960), vol. 1, 98, cat. no. 58. For the inventory, see Adriaan van der Willigen and Fred G. Meijer, A Dictionary of Dutch and Flemish Still-Life Painters, Working in Oils, 1525-1725 (Leiden: Primavera Press, 2003), 161.

36 See, for similar wills, Katlijne Van der Stighelen, "Van 'marchant' tot 'vermaert conterfeyt': het levensverhaal van Cornelis de Vos," Jaarboek van het Koninklijk Museum voor Schone Kunsten (1991): 87-156. I am grateful to Prof. Van der Stighelen for this reference. 
What can be learned by studying the relationship between artists and their servants? First, artists are implicated in the class system, and considering class as a category of analysis can illuminate their lives and their works. For example, Simon Schama linked Rembrandt's relationship to Geertje Dircx to his most sexually explicit prints, produced around the time that they were lovers. ${ }^{37}$ But artists' biographies can also illuminate servants' lives. Dircx's life is so well documented because her master was, to quote one court document, "the honorable and renowned painter" Rembrandt. ${ }^{38}$ Similarly, investigating Maria van Oosterwijk's servant reveals a previously unknown path by which women could become professional artists. ${ }^{39}$

\section{$2 \quad$ Portraits of Servants}

Although Geertje Dircx owned a portrait of herself, no likeness of her, Hendrijcke Stoffels, or Geertje Pieters can be securely identified today.$^{40}$ But it is likely that actual servants posed as models for painted ones. ${ }^{41}$ For example, a drawing by Frans van Mieris of a woman of African descent, which served as the basis for a painting of a servant, may well be a portrait of a domestic worker (Figs. 7.1, 7.7). ${ }^{42}$

Similarly, in Jacob Jordaens' self-portrait with his wife and daughter, not only is the servant's face individualized, but also her arthritic hands (Fig. 7.8)..$^{43}$ If this is a portrait of his servant, however, she has never been identified by name.

37 Schama, Rembrandt's Eyes, 543 .

38 Hofstede de Groot, Die Urkunden, 142; Schama, Rembrandt's Eyes, 543 ("eersamen, wijtvermaerden Schilder").

39 This path is not mentioned in Sheila ffolliott's comprehensive study of early modern women artists. See "Early Modern Women Artists," in Ashgate Research Companion to Women and Gender in Early Modern Europe, ed. Allyson M. Poska, Jane Couchman, and Katherine A. McIver (Farnham, Ashgate, 2013), 423-43.

40 One of two drawings by Rembrandt showing a woman in a north Holland costume is inscribed on the reverse in a seventeenth-century hand, "De minne moer van Titus," that is, "Titus's nurse." For the inscription, see Otto Benesch, The Drawings of Rembrandt (London: Phaidon Press, 1954), vol. 2, 76, cat. nos. 314, 315. Since Titus was not born until 1641 and the drawing is dated before then, the inscription cannot refer to Dircx.

41 Paul Kaplan, "Italy, 1490-1700," in Image of the Black in Western Art, ed. David Bindman and Henry Louis Gates, Jr. (Cambridge, MA and London: Harvard University Press, 2010), vol. 3, part 1, 181-182 (Pietro Moro), 107-110 (Laura Dianti). I would like to thank Paul Kaplan for this reference and for many fruitful discussions.

42 Van der Ploeg, "Woman before a Mirror," 157-59.

43 See Watteeuw, "Household names," 55. for this painting, and for the sitter's arthritis see Jan Dequeker, "A Physician's View Beyond the Curtains of Seventeenth-Century Flemish 


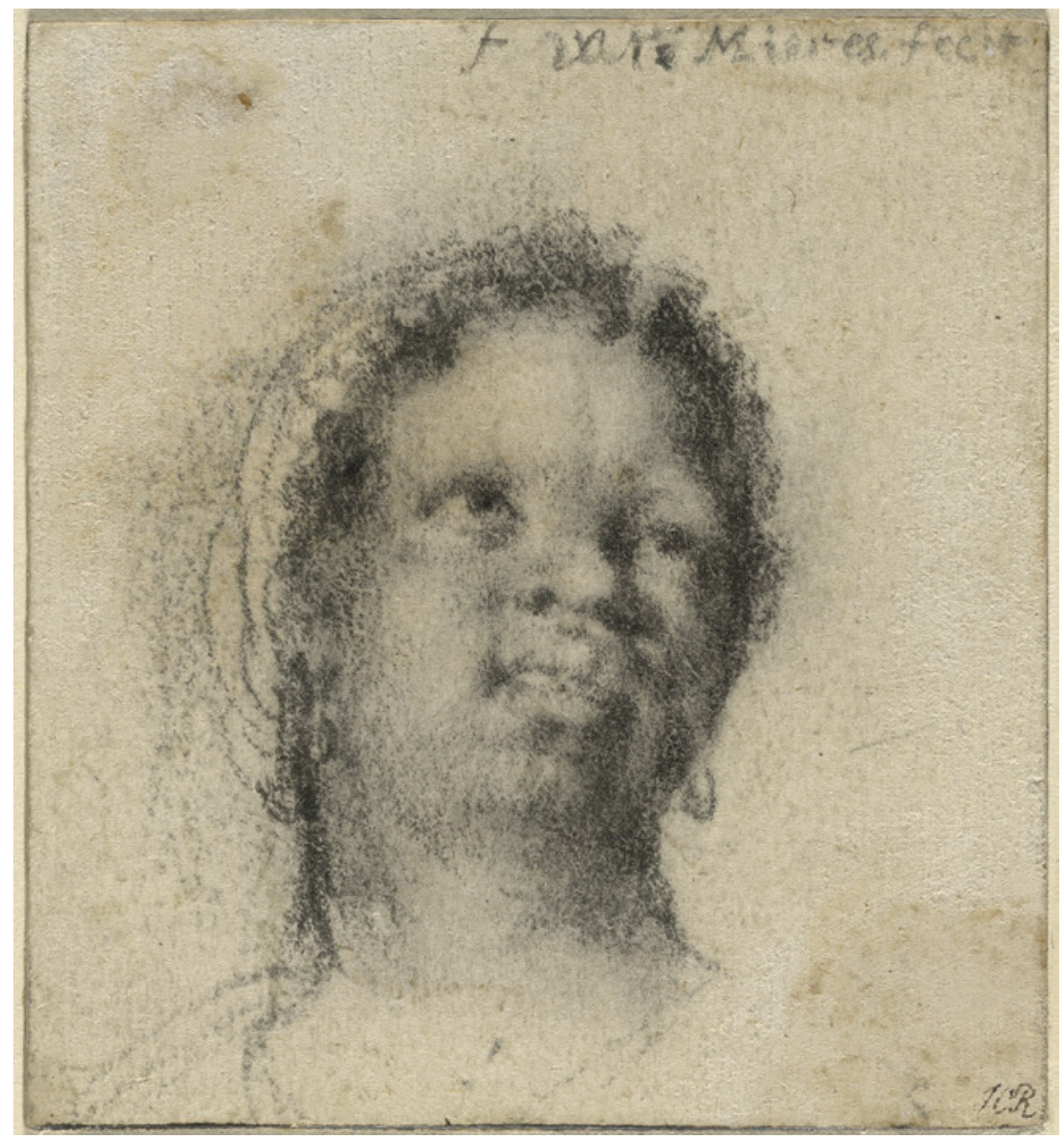

FIGURE 7.7 Frans van Mieris the Elder, Head of a Black Woman, 1650-1681, The British Museum, London

Perhaps the most famous painting of a Netherlandish female servant appears in Frans Hals' portrait of Catharina Hooft and her nurse (Fig. 7.9). ${ }^{44}$ An inventory, dated 1709, of the estate of Catharina's son describes it as "a nurse (minne)

and Dutch Baroque Portraits," in Pokerfaced, ed. by Katalijne van der Stighelen, Hannelore Magnu, and Bert Watteuw (Turnhout: Brepols, 2010), 101-102.

44 For the identity of the child, see S. A. C. Dudok van Heel, "Een minne een kidje door Frans Hals," Jaarboek van het Centraal Bureau voor Geneaologie 29 (1975): 146-59. For this painting, see Seymour Slive, Frans Hals (Washington, London, Haarlem: Prestel, 1989), 154; Quentin Buvelot, "Portrait of Catherine Hooft and her Nurse," in Dutch Portraits: The Age of Rembrandt and Frans Hals, ed. Rudi Eckart and Quentin Buvelot (The Hague: Royal Picture Gallery Mauritshuis, 2007), 104, 239. 


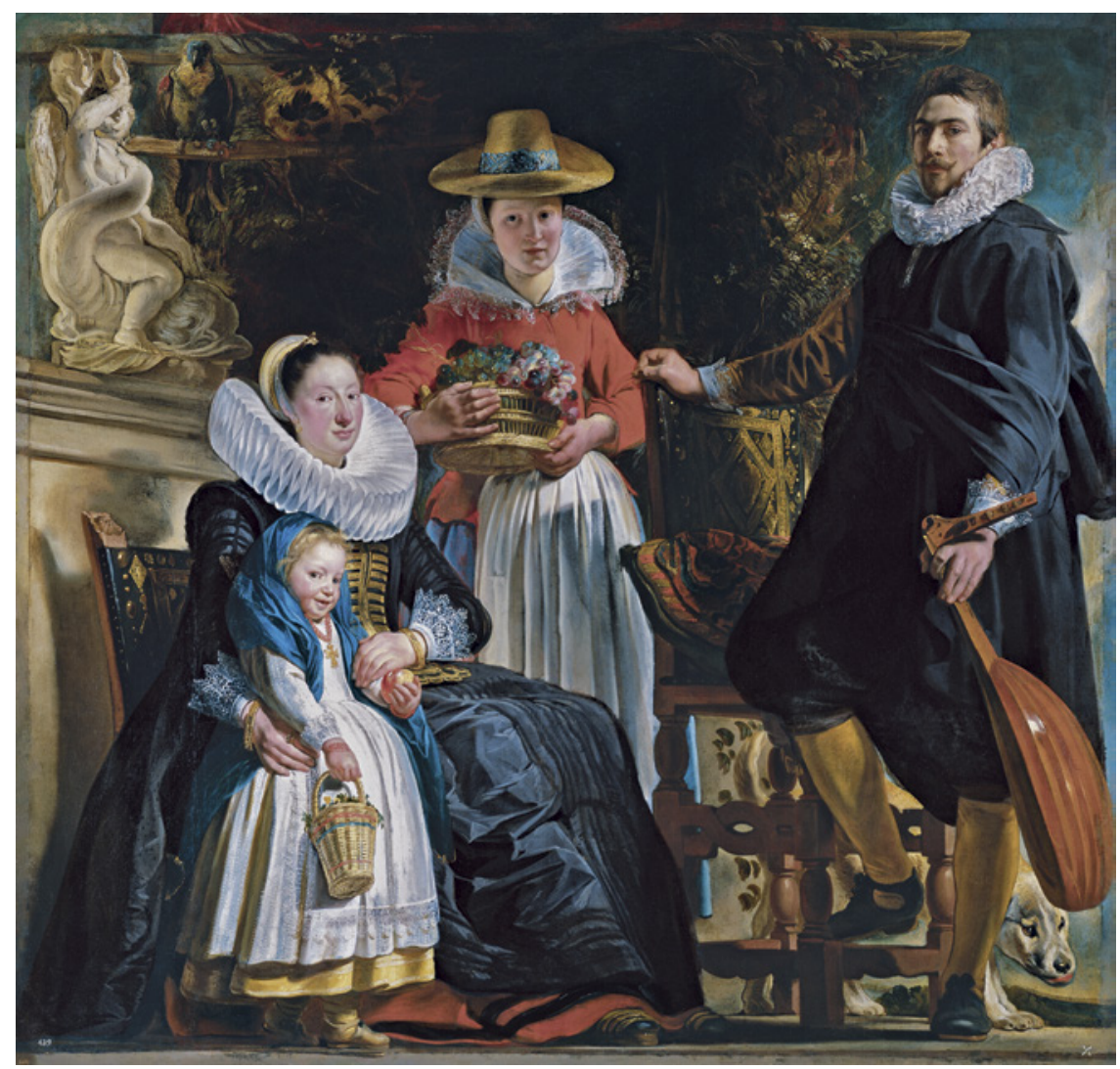

FI GURE 7.8 Jacob Jordaens, Self-Portrait with Family and Servant, 1621-22, Museo Nacional del Prado, Madrid

with a young child by Frans Hals."45 The painting must show a nurse rather than a mother because the sitter's ruff is old-fashioned and her garments are plain, which contrasts strikingly with the child's sumptuous lace bib, rich floral-and-vine patterned gold brocade dress, and gold bracelets, necklace, and

45 Slive, Frans Hals, 154: "minne met een kindje van Frans Hals." The provenance of the painting may be traced back to its original owner. An inventory composed after Hooft's death in 1691 describes the picture, which was displayed in the salon, as "1 painting of a babe in arms in the direct family line" (" 1 schilderij zijnde een kind op de arm 't geslagt Raakende"), for which see ibid., 154. The painting remained in Hooft's house even after she gave it to her son, and was displayed in a room favored by her daughter-in-law. See Klaske Muizelaar and Derek L. Phillips, Picturing Men and Women in the Dutch Golden Age: Paintings and People in Historical Perspective (New Haven: Yale University Press, 2003), 77. 


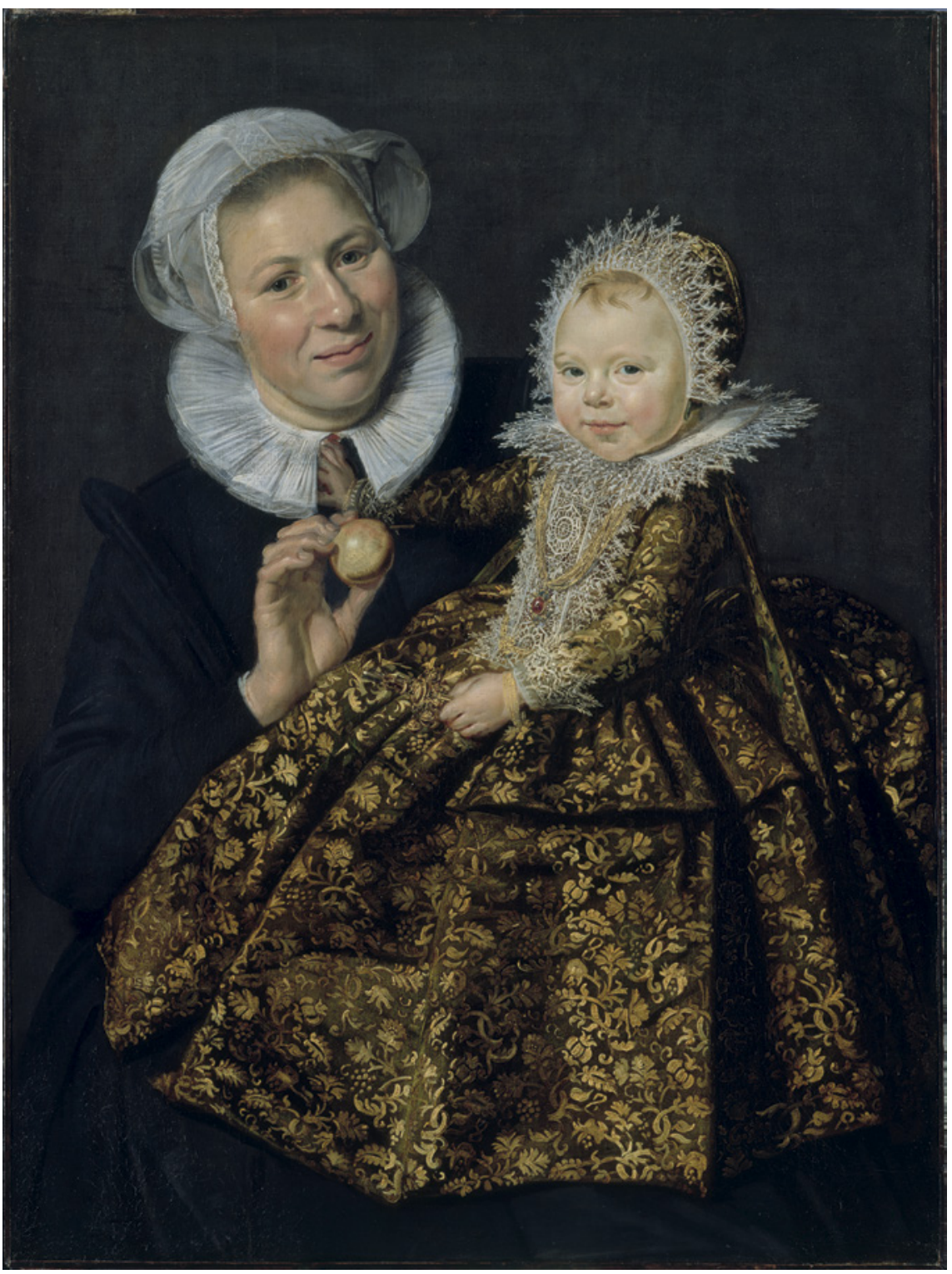

FIGURE 7.9 Frans Hals, Catherina Hooft and her Nurse, 1619-20, Staatliche Museen zu Berlin, Gemäldegalerie 
rattle. The nurse offers the girl an apple, as she, in turn, affectionately rests her right hand against the woman's chest. Both figures smile at the viewer, the woman warmly, the child mischievously. ${ }^{46}$ The lack of a padded hat, the leads attached to the back of the child's garment, and the length of her dress, which is longer than her legs, suggest that she still needed support to ambulate.

We should not be surprised that the nurse remains unidentified; more than half of Hals' sitters remain anonymous. ${ }^{47}$ But Seymour Slive asks why the nurse was included at all, terming it an unusual subject. ${ }^{48}$ Caregivers are often pictured in later group portraits of Dutch families, identifiable when the mother, more richly dressed and centrally placed, is also present. Contemporary with Hals' portrait is one showing Sophia Hedwig, Countess of Nassau-Dietz, as Charity with three of her sons. ${ }^{49}$ In the background a young woman, presumably a servant, holds a baby, probably the daughter of the Countess. Pieter de Hooch similarly shows in the background of another family portrait a nurse and infant, this time beside a young girl and in a separate room. ${ }^{50}$ In portraits by Frans Hals, Gabriel Metsu, and Jacob Ochtervelt, the nurse is placed off to the side, wears a plain black garment with white collar, and holds the child in her arms, much as in Hals' earlier double portrait (Figs. 7.9-7.10).51

Although only one Dutch portrait survives of a nurse with her charge but without her employer, examples from other regions are extant. In 1638-39, Philip Fruytiers painted two caregivers with four children of his teacher Peter

46 The painting is undated, but based on the age of Catherina, who was born in December 1618 and the date, February 1619, when she moved to Haarlem where Hals worked, it must have been produced in 1619 or 20. See Pieter J. J. van Thiel, "Frans Hals, Catherina Hooft and her Nurse," in Dawn of the Golden Age: North Netherlandish Art 1525-1580 (Amsterdam: Rijksmuseum, 1993), 601.

47 Slive, Frans Hals, 9.

48 Ibid., 154.

49 Peter van der Ploeg, "Portrait of Sophia Hedwig, Countess of Nassau-Dietz, as Charity, with her Children," in Dutch Portraits in the Age of Rembrandt and Frans Hals, ed. Rudi Eckart and Quentin Buvelot (The Hague: Royal Picture Gallery Mauritshuis, 2007), 168-69.

$50 \quad$ Perry Chapman, "Home and the Display of Privacy," 134 in Art and Home: Dutch Interiors in the Age of Rembrandt, ed. Mariët Westermann (Denver: Denver Art Museum and Newark: Newark Museum, 2001).

51 See Familienglück: Rembrandt und sein Braunschweiger Meisterwerk (Braunschweig: Herzog Anton Ulrich-Museum, 2006), 62, fig. 8 for the Ochtervelt portrait. For Hals' portrait see London, National Gallery, inv. no. 2285 (1647-50). In Jan Mijten's portrait, the caregiver is clearly marked as a wet nurse by her bare breast; see Alexandra Nina Bauer, Jan Mijtens (1613/14-1670): Leben und Werk (Petersberg: Michael Imhof, 2006), 237-38. Prints also show a child and nurse; see Pieter van den Berge, A Nurse from Waterland, ca. 1700 . 


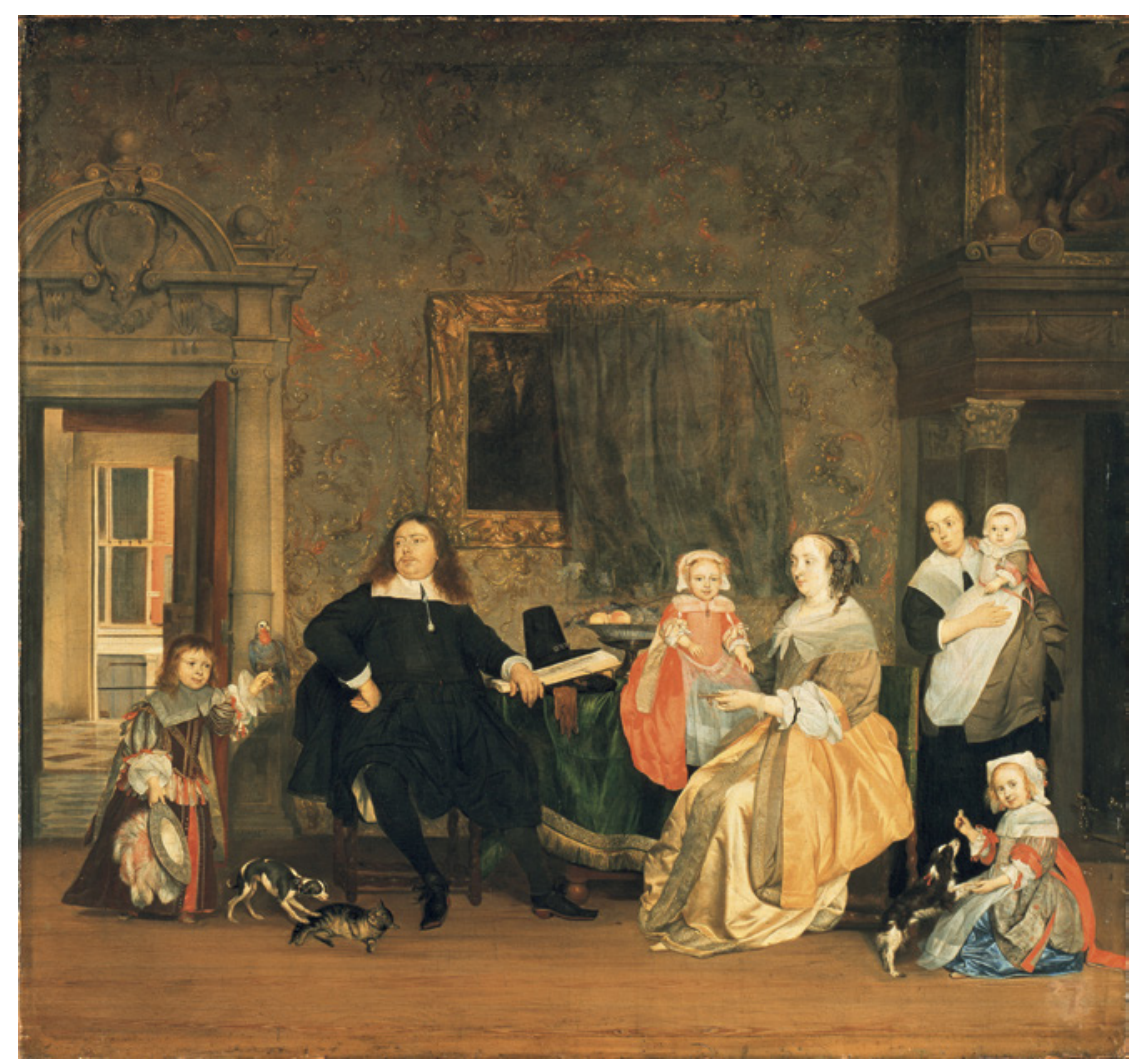

FIG URE 7.10 Gabriel Metsu, Portrait ofJan Jacobsz. Hinlopen and His Family (or the Burgomaster Dr. Gillis Valckenier), c. 1655, Staatliche Museen zu Berlin, Gemäldegalerie

Paul Rubens. ${ }^{52}$ Although the portrait of Catherina Hooft and his nurse seems exceptional, this is only because it is usually explored in the context of Dutch art. The portrayal by Hals, however, is especially close to an earlier one showing a smiling nurse holding Cosimo II de' Medici, dated $1590 . .^{53}$ Other Italian examples include Moretto da Brescia's portrait of an unidentified boy with his nurse and Justus Sustermans's painting of Ferdinando III, Anna Maria Luisa de' Medici, and their governess. ${ }^{54}$ Similarly, in France, Henri and Charles

52 Desmond Shawe-Taylor and Jennifer Scott, Bruegel to Rubens: Masters of Flemish Painting (London: Royal Collection Enterprises, 2007), 148. For their possible names, see Watteeuw, "Household names," 63.

53 The anonymous Italian portrait is in the Uffizi, Florence.

54 Moretto's painting, dated 1547-49, is in the Hermitage, St. Petersburg; Susterman's, ca. 1670, is in the Museo Stibbertin, Florence. Jean van Belcamp painted a triptych for Ann Clifford 
Beaubrun portrayed the Dauphin and his wet nurse, who was shown with a bare breast. ${ }^{55}$

Nurses were included in portraits in part because they often formed a bond of affection with the children in their care. Infants were generally weaned at their first birthday, and then wealthy families hired either their wet nurse or another woman to care for the child. ${ }^{56}$ Elisabeth Strouver, hired at the age of sixteen or seventeen, wrote after the death of the four-year-old girl who had been her charge for three years, "A mother could not be more affected by the death of her child than I was; I lay my head against the head of the dead child, and could hardly be stopped, although her face had been terribly disfigured by smallpox." ${ }^{\prime 7}$ Closer in tone to Hals' portrait is the statement by Constanijn Huygens about a wet nurse that he had hired: "she was a good, kind-hearted woman with a healthy constitution and a steadfast disposition."58

Only one Netherlandish portrait of a female servant whose name is known survives, Pieter van der Hulst's likeness of Live Larsdatter, the housekeeper of the Danish scientist Tycho Brahe (Fig. 7.11). ${ }^{59}$ She wears a dark dress and large white collar, and holds keys in her right hand and a white cloth in her left. She stands beside a column on which is tacked a paper that cites the date and place of her birth, the place of her baptism, and the date and place of her death. Van der Hulst worked in Denmark in the 169os, and this portrait was painted in 1698 when Larsdatter was believed to have been well over a hundred years old. This is not the only portrait of an elderly housekeeper; twelve years earlier

that includes her governess; see Zirka Z. Filipczak, "Portraits of Women Who 'Do not Keep Strictly to the Masculine and Feminine Genders, as They Call Them,"' in Pokerfaced, 241. By contrast, a portrait by John Riley and Johann Baptiste Closterman shows Katherine Elliot alone. Presumably commissioned by James II or one of his daughters, this painting depicts the woman who had been the king's nurse and later became Dresser and Woman of the Bedchamber to both his wives. See Oliver Millar, The Tudor, Stuart and Early Georgian Pictures in the Collection of Her Majesty the Queen (London: Phaidon Press, 1963), 140. See also J. E. Sartorino, Nurse with Child, seventeenth century.

55 Henri and Charles Beaubrun, The Dauphin Louis of France and his Nursemaid, Dame Longuet de la Giraudiere, ca. 1638, Versailles, Châteaux de Versailles et de Trianon.

56 Rudolf Dekker, Childhood, Memory and Autobiography in Holland. From the Golden Age to Romanticism (London: Macmillan, 2000), 25, 34. Dutch wet nurses earned seven guilders a month according to Ibid., 99 .

57 Ibid., 130 (quote); Florence Koorn, "A Life of Pain and Struggle. The Autobiography of Elisabeth Strouven (1600-1661," in Autobiographien von Frauen:Beiträge zu ihre Geschichte (Tübingen: Max Niemeyer Verlag, 1996), 13-23.

$5^{8} \quad$ Dekker, Childhood, 26.

59 For this painting, see John Robert Christianson, On Tycho's Island: Tycho Brahe and his Assistants, 1570-1601 (Cambridge: Cambridge University Press, 2000), 311. 


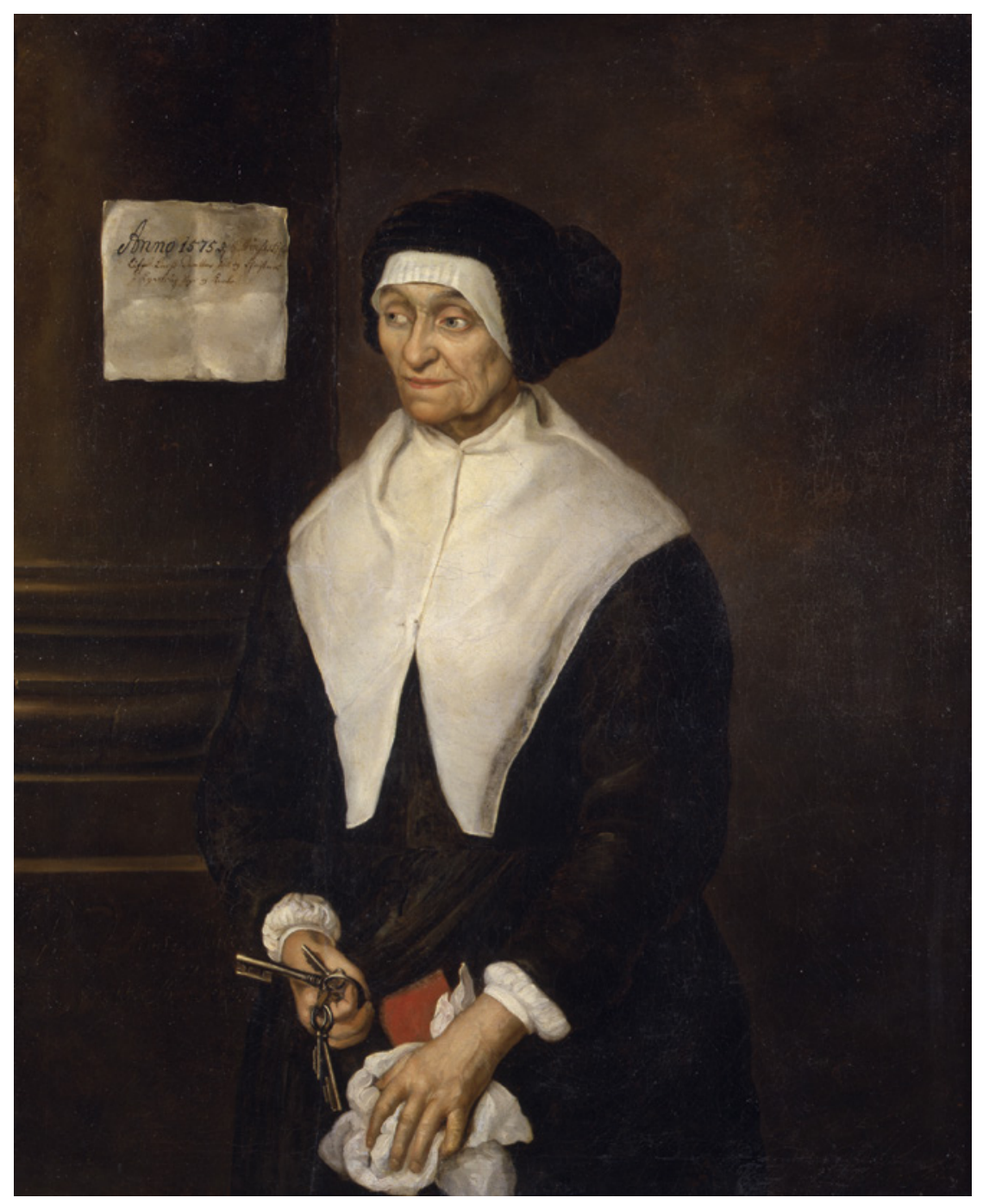

FIGURE 7.11 Pieter van der Hulst, Live Larsdatter, 1698, Museum of National History, Frederiksborg Castle, Hillerød, Denmark

John Riley painted a portrait of the 'Necessary Woman' Bridget Holmes, who had long served the English royal family. ${ }^{60}$

6o Susan Broomhall and Jennifer Spinks, Early Modern Women in the Low Countries. Feminizing Sources and Interpretations of the Past (Farnham and Burlington: Ashgate, 2011), 122. 


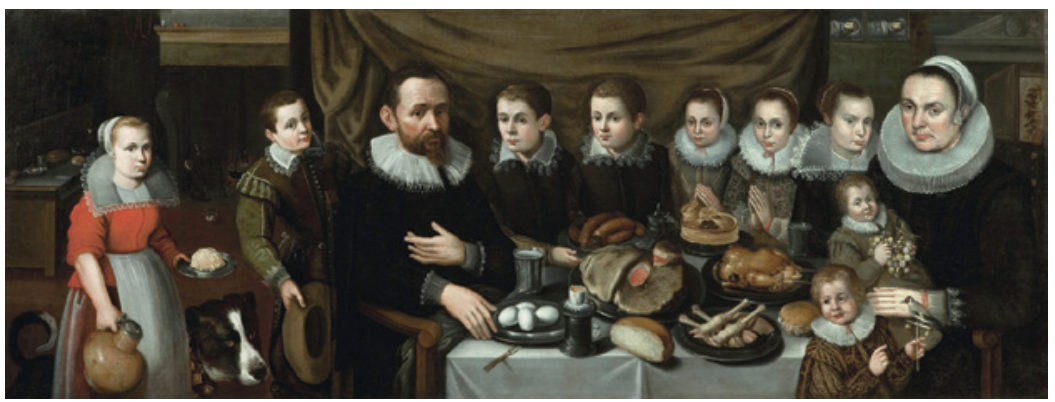

FIGURE 7.12 Anon. (Flemish school), Family Portrait with Servant, 1610s, private collection

The two portraits by Dutch painters that feature a female servant by showing her either alone or with a child portray workers of a relatively high status, a nurse and a chief housekeeper (Figs. 7.9, 7.11). Statistics are not available for Southern Netherlandish households, but only $10 \%$ of Dutch homes had servants, and the vast majority of those had only one, a maid-of-all-tasks. ${ }^{61}$ Such servants appear in portraits, but they cannot be identified by name. One little-known representation of a servant girl who appears in a Flemish family portrait is typical (Fig. 7.12) ${ }^{62}$ Dressed much like Jordaens' servant, in a red jacket with raised lace collar and a white apron (Fig. 7.8), her social position is marked by her actions and location. Like Jordaens' maid, the girl serves food, in this case a mound of butter and a ceramic jug of beer, and she stands before the kitchen, the site of her labor. Like so many images of servants, her secondclass status is made clear. She is pushed to the far left of the composition and separated from the family she serves by another loyal household member, the dog. In addition to her act of serving food, a small detail suggests that she, unlike the family members, is working: one of her sleeves is rolled up to the elbow baring her strong forearm, as in so many Netherlandish images of female kitchen workers. ${ }^{63}$

61 The wealthiest Dutch households employed more than one servant, including cooks, valets, errand boys, coachmen, laundresses, wet nurses, and maids. See Dekker, Family, Culture and Society in the Diary of Constantijn Huygens Jr. (Leiden: Brill, 2013), 141, 143.

62 I thank Lawrence Steigrad, President, Peggy Stone, Vice-President, and Alexandria Edelson, Director, of the Lawrence Steigrad Fine Arts gallery for information concerning this painting. Rosie Kosinski, formerly employed by the gallery, was also helpful.

63 For other paintings of kitchen workers with raised sleeve and bared forearm, see the those by Pieter Aertsen, Joachim Beuckelaer, and Pieter Cornelis van Rijck, among others. This motif also appears in images of male kitchen workers. For a modern example from the United States, see the poster of Rosie the Riveter. 
Jordaens' monumental portrait of 1621-22 may have been painted to commemorate his election as dean of the Antwerp Guild of St. Luke. In many ways this painting conforms to the dominant paradigm. The artist strikes a gentlemanly stance and his servant, like the courtly garden in which he stands, may have been included to enhance his status. Catherina van Noort, the painter's wife, overlaps the servant, pushing her slightly to the middle ground, and Catherina's face is bathed in light, whereas her servant's is cast in shadow. The servant's clothes and her act of holding a basket of fruit make clear her occupation. Nonetheless Jordaens' depiction is unique among group portraits in its emphasis on the servant. Here she is the central figure and the only one to face frontally. Nor does she function as a negative foil for her mistress as so many other servants do (Figs. 7.1, 7.5, 7.18). She seems no older or uglier than Catherina, for example; $; 4$ in fact, her handsome face is characterized by a subtle, radiant luminosity. She neither bends obsequiously towards her employers nor gazes admiringly at them as so many servants in portraits do. Just as the painting as a whole suggests the harmony and love of Jordaens's family through such standard signs as the the garden of love, the loyal dog, the harmonious lute, and the clinging vine, so does the servant stand for immaterial qualities, contributing to the work's celebration of love, abundance, concord, and fertility. ${ }^{65}$

But why is she such a central figure? Jordaens may have wanted to grant his servant a more important role in order to express his affection for or appreciation of a loyal member of his household. Perhaps, like Geertje Pieters, she was also a distant relative. But in addition she may have been highlighted because Jordaens, unlike his Flemish colleagues Rubens and Van Dyck, was neither a humanist nor a court painter. Because the courts of Spain and

64 See, by contrast, "Roman lady with older servant holding a rosary," in Album Amicorum of Paul van Dale, Oxford, Bodlean Library, MS. Douce d. 11, fol. o2or, ca. 1569-1578.

65 For a discussion of these symbols, see Kristi Nelson, "Jacob Jordaens: Family Portraits," Leids Kunsthistorisch Jaarboek 8 (1989): 107, 109 [105-119]; R.-A. d'Hulst, "Self-portrait with Parents, Brothers, and Sisters, in Jacob Jordaens (1593-1678). Vol I. Paintings and Tapestries, ed. Hans Devisscher and Nora de Poorter (Amsterdam: Royal Museum of Fine Arts, 1993), 54; R.-A. d'Hulst, Jacob Jordaens, trans. P. S. Falla (Ithaca: Cornell University Press, 1982), 270; Hans Vlieghe, Flemish Art and Architecture 1585-1700, trans. Alastair and Cora Weir (New Haven and London: Yale University Press, 1998), 125, 127. Nobert Schneider argues, without basis, that this central figure is not a servant because in seventeenthcentury family portraits the role of holding a basket of grapes is assigned to a child. $\mathrm{He}$ also asserts, without foundation, that she appears to be thirteen to fifteen years old, that the grapes symbolize the strength of the family, and that the figure may be the daughter of Jordaens, and so the painting dates $1628-30$. See The Art of the Portrait (Cologne: Taschen, 2002), 142. 
Brussels did not favor his work, Jordaens could be free of the restrictions imposed by court decorum. ${ }^{66}$ Indeed he was drawn to what Hans Vlieghe terms the "popular element." 67 His early Adoration, for example, places an unusual emphasis on shepherds and animals. ${ }^{68}$

Yet despite the major role of the servant, Vlieghe recently interpreted the painting this way:

[The] portrait Jordaens painted of himself, his wife and their little daughter in 1621-2 may show that he, too, had meanwhile come to understand the importance of the nuclear family as the primary social unit. Here there is again the traditional emblematic play on love, family, harmony and fertility seen in such elements as the arbour in the garden, flowers, fruit and a lute. ${ }^{69}$

It is remarkable that this distinguished scholar terms the figures a nuclear family when the servant is clearly not a member of that category. Indeed, he describes the presence of Jordaens, his wife, his daughter, and even the flowers, lute, and fruit, while failing to mention the large, brightly colored figure at the very center of the composition. The servant remains invisible to him. ${ }^{70}$

Only one of the servants portrayed by Dutch and Flemish painters can be identified, which recalls Pieter J. J. van Thiel's statement that "There is something sad about an anonymous historical portrait. It is the likeness of someone who has died twice, as it were, first physically and then existentially, for a person continues to exist, in a sense, for as long as a portrait keeps his or her memory alive." ${ }^{71}$ Yet this group of servants' portraits is exceptional because portraiture was traditionally reserved for the elite, who through lineage or accomplishment were deemed worthy of immortality. ${ }^{72}$ What cultural role,

\footnotetext{
66 Ibid., 35 .

67 Ibid., 59 .

68 Ibid., 36.

69 Vlieghe, Flemish Art and Architecture, 127. For fruit as a sign of fertility, see Jan Baptiste Bedaux, "Fruit and fertility: Fruit Symbolism in Netherlandish Portraiture of the Sixteenth and Seventeenth Centuries," Simiolus 17 (1987): 150-68.

70 Vlieghe, Flemish Art and Architecture, 127.

71 Van Thiel, "Frans Hals, Catherina Hooft, and her Nurse," 6o1. Thiel suggests that it derives from images of the Madonna and Child.

72 For other images of servants, see Diane Wolfthal, Household Help: Images of Servants and Slaves in Europe and Abroad, 1400-1700 (under contract to Yale University Press), and Wolfthal, "Household Help."
} 
then, do portraits of servants play? ${ }^{73}$ Certainly they are at times meant as foils for the elite, since through their dress and location they are marked as lower in rank. When included in a family portrait, servants often add status, since so few Netherlandish households could afford hired help. When servants are portrayed as loyal, industrious, and obedient, they suggest a well-run household, and Live Larsdatter was probably also represented because of her extraordinary longevity. ${ }^{74}$ But servants differ from others of low status, such as peasants and beggars, in their intimate long-term contact with the elite. For this reason, they may sometimes have been included at least in part because of ties of affection.

Few of us consider housework an exciting or elevating endeavor, but it is a necessary one. As scholars we must examine our assumptions, including those that exalt some occupations while trivializing others. As art historians, we cannot turn a blind eye to servants, especially when painters like Hals, van der Hulst, and Jordaens sometimes portray them as central figures with great dignity.

\section{Doll Houses}

In addition to artists' biographies and portraits of servants, material culture can shed new light on domestic workers. The sturdy chamber pots that they washed, the beds that they made, the presses that they screwed tight to produce crisp folds in linen, and the intricate carvings of the massive cupboards that they dusted all offer evidence of the nature of servants' labor. ${ }^{75}$ But this essay will focus on another type of object, doll houses. In the last thirty years, scholars have begun to examine early modern Dutch doll houses through surviving inventories, eye-witness accounts, Jacob Appel's painting

73 Joanna Woodall, "Sovereign Bodies: the Reality of Status in Seventeenth-Century Dutch Portraiture," in Portraiture: Facing the Subject, ed. Joanna Woodall (Manchester: Manchester University Press, 1997), 75-100.

74 Wolfthal, "Household Help."

75 For linen presses, cupboards, and other furniture, see Loek van Aalst, "Dutch Furniture from the Golden Age," in Golden Dutch and Flemish Masterworks from the Rose-Marie and Eijk van Otterloo Collection. ed. Frederik J. Duparc (New Haven: Yale University Press, 2011), 344-375. For the varied meanings of brooms, see Eddy de Jongh, Questions of Meaning: Themes and Motif in Dutch Seventeenth-Century Paintings, trans. and ed. Michael Hoyle (Leiden: Primavera Press, 1995), 194-214. For Dutch kettles, see Alexandra van Dongen, “'The Inexhaustible Kettle': The Metamorphosis of a European Utensil in the World of the North American Indian," in One Man's Trash is Another Man's Treasure (Rotterdam: Museum Boymans-van Beuningen, 1996), 115-133. 


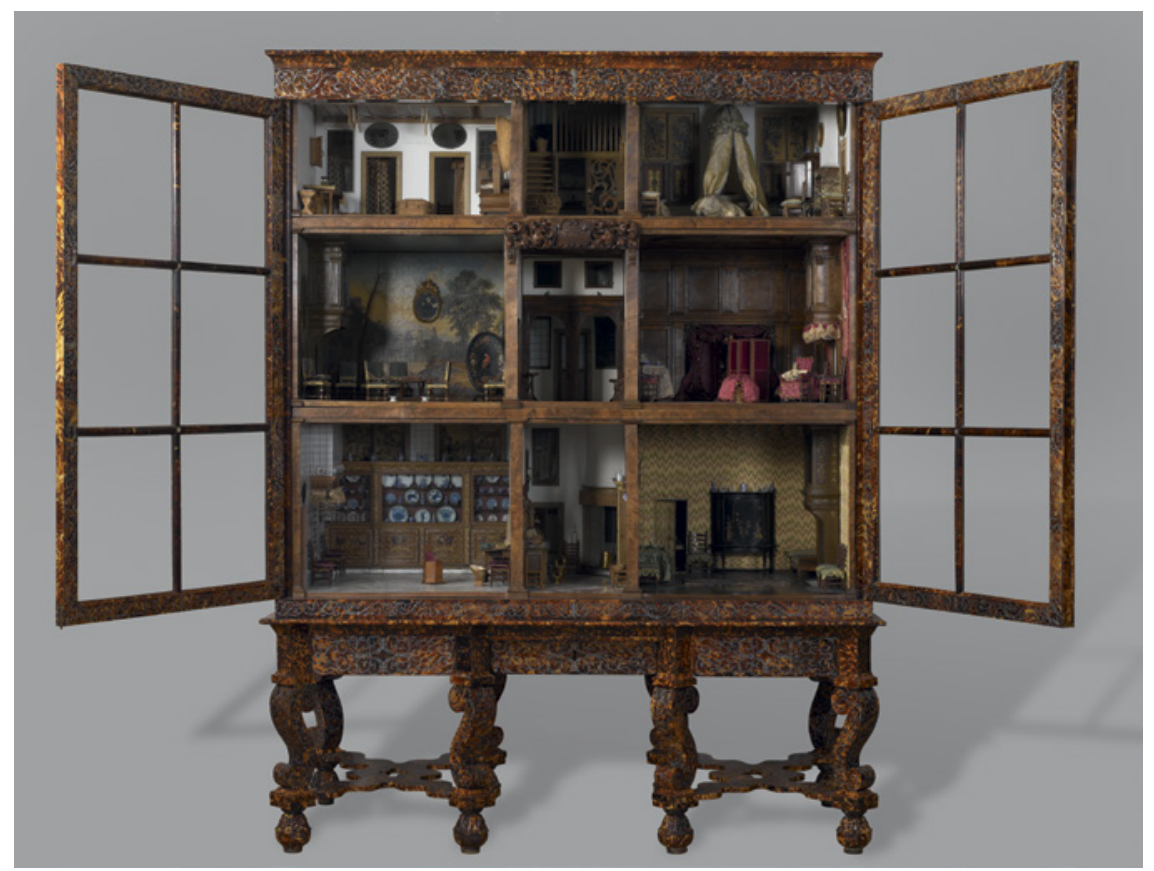

FIGURE 7.13 The dolls' house of Petronella Oortman, c. 1685-1705, Rijksmuseum, Amsterdam

after Petronella Oortman's doll house, and the three surviving examples: Oortman's and those commissioned by Petronella de la Court and Petronella Dunois (Figs. 7.13-7.14). ${ }^{76}$

Beginning in the 1980s, Jet Pijzel-Dommisse's flurry of publications comprehensively examined the patronage, provenance, and production of doll houses, and exhaustively catalogued all surviving dolls and furnishings. ${ }^{77}$ This led to more interpretive studies. In 2003, Melinda K. Vander Ploeg Fallon explored the collecting practices of Petronella de la Court, and four years later

76 Constance Eileen King, The Collector's History of Doll Houses, Doll's House Dolls, and Miniatures (London: R. Hale and New York: St. Martin's Press, 1983), 99-129; Jet PijzelDommisse, Het poppenhuis Petronella de la Court (Utrecht: Centraal Museum, 1987); Pijzel-Dommisse, The 17th-century Dolls' Houses of the Rijksmuseum, trans. Patricia Wardle (Amsterdam: Rijksmuseum, 1994); Pijzel-Dommisse, Het Hollandse pronkpoppenhuis: Interieur en huishouden in de 17de en 18de eeuw (Amsterdam: Rijksmuseum, 2000). The Oortman House, built in 1686-9o and furnished in 1690-1705, and the Dunois House of 1676 are in the Rijksmuseum, Amsterdam. The de la Court house, dated ca. 1674, is in the Centraal Museum, Utrecht.

Ibid. 


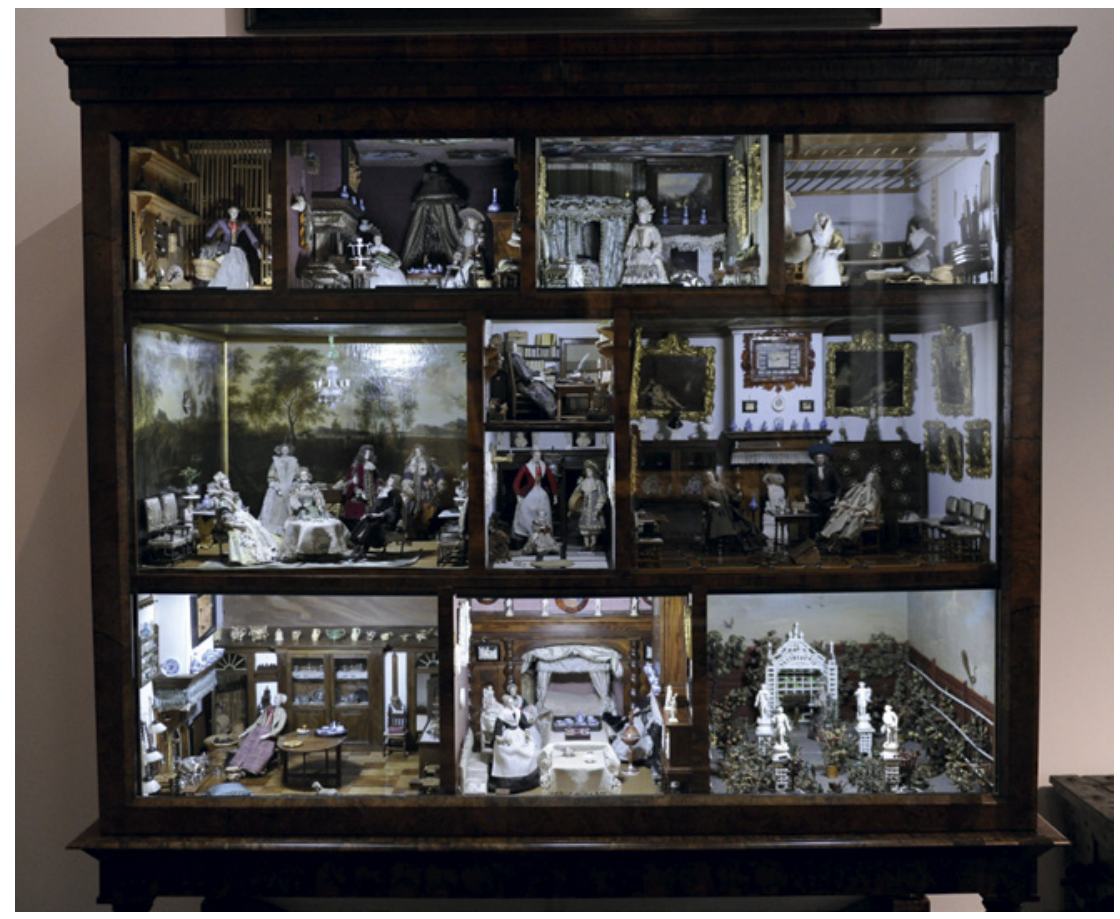

FIGURE 7.14 Dolls' house of Petronella de la Court, 1670-169o, Centraal Museum, Utrecht

Susan Broomhall analyzed how women's ideas about household spatial and social ordering were expressed through Dutch doll houses. ${ }^{78}$ Finally, in 2010 Michelle Moseley-Christian employed materiality and performance theory to understand how Dutch women interacted with doll houses. ${ }^{79}$

All those who have studied these objects agree that, to quote Broomhall, "here was a world of fantasy, where the house was always clean under the attention of the maids, disciplined children played under the care of $a[n]$ orderly nanny, friends and neighbors enjoyed tea and conversation whilst paying their respect to the new mother, and the master of the house was rarely

78 Linda K. Vander Ploeg Fallon, "Petronella de La Court and Agneta Block: Experiencing Collection in Late Seventeenth-Century Amsterdam," Aurora 4 (2003): 95-108; Susan Broomhall, "Imagined Domesticities in Early Modern Dutch Dollhouses," Parergon 24 (Nov. 2007), 47-67. Broomhall later published this material in Broomhall and Spinks, Early Modern Women, 99-122.

79 Michelle Moseley-Christian, "Seventeenth-Century Pronk Poppenhuisen: Domestic Space and the Ritual Function of Dutch Dollhouses for Women," Home Cultures 7.3 (Nov. 2010): 341-363. 
to be seen." ${ }^{80}$ As expressions of an upper-class ideal, doll houses differentiate maids from mistresses. Servants wear plainer, coarser garments than the elite, for example, in the de la Court house (Fig. 7.14). ${ }^{81}$ But the dolls also suggest a hierarchy among servants. In the de la Court house, the kitchen maid at the lower left wears much rougher clothes - a checked skirt and tan jacket - than the childcare worker in the central vestibule on the middle floor. ${ }^{82}$ And in the Dunois house the distinctive work of the wet nurse is made clear by the flap in her bodice that opens to reveal her breasts (Fig. 7.15). This doll, together with the positive statements that Constantijn Huyghens writes about wet nurses, which are cited above, and the idealized family portraits that include wet nurses with one bare breast, serve as a sharp contrast to the widespread movement that promoted mothers' breastfeeding. ${ }^{83}$ Jacob Cats wrote extensively in this vein, and reformed authors, including John Calvin and William Perkins, did as well. ${ }^{84}$ Similarly, images of Charity and, especially for Catholics, those showing the nursing Virgin contribute to this ideology of motherhood. ${ }^{85}$

Doll houses also distinguish the rooms of the elite from those of servants. In the Oortman house, the maids' living quarters are in the rear of the top floor, hidden from view behind the laundry room at the top left, and sparsely furnished with a bed, chair, and chamber pot (Fig. 7.13). Similarly, in the de la Court house, a wooden divider separates the storage room at the top left from the maid's chamber behind it, which is, in turn, linked to the peat and wood loft to the right (Fig. 7.14). Once again, the servant's room is hidden from view and located in a less desirable part of the house. Furthermore, the servants' rooms are smaller, their beds more simply designed, and their bed linens more modest in pattern and material. By contrast, the rooms of the elite are larger, more centrally placed, and more opulently furnished. These

8o Broomhall and Spinks, Early Modern Women, 122.

81 For the seventeenth-century date of these clothes, see Pijzel-Dommisse, Het Hollandse pronkpoppenhuis, 169 and 238 .

82 King, The Collector's History of Doll Houses, 111.

83 For portraits of wet nurses with one breast bare, see notes 51,55 .

84 See Alice Clare Carter, "Marriage Counseling in the Early Seventeenth Century: England and the Netherlands Compared," in Ten Studies in Anglo-Dutch Relations, ed. Jan van Dorsten, (Leiden and London: Leiden University Press and Oxford University Press, 1974), 94-127, especially 96 note 11 and 98 note 11 ; for Cats, see the edition of W. J. Hofdijk. Tiel, 1861, 276i and 278ii. For Cats, Calvin, and Dutch breastfeeding practices, also see Frima Fox Hofrichter: "An Intimate Look at Baroque Artists," in Framing the Family: Narrative and Representation in the Medieval and Early Modern Periods, ed. Diane Wolfthal and Rosalynn Voaden. 143-46.

85 For Charity, see the painting cited in note 49, and the title pages of Adrian Hoffer's Nederduytsche Pöemata, (Amsterdam: Broer Jansz., 1635). 


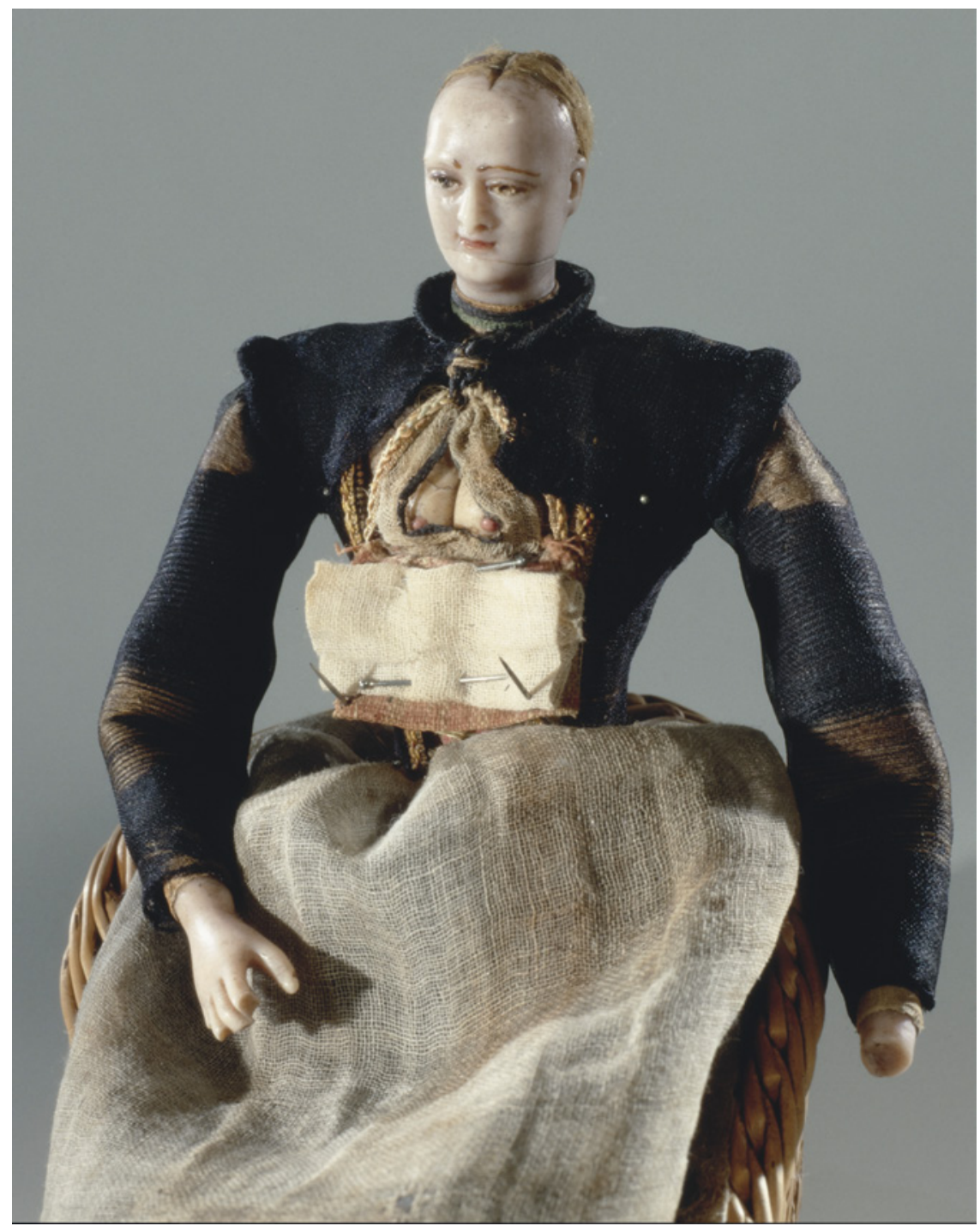

FIGURE 7.15 Nurse, Dolls' house of Petronella Dunois, c. 1676, Rijksmuseum, Amsterdam

features reflect historical reality. A seventeenth-century probate inventory, for example, reveals that two servants in Amsterdam, Lysbeth Arrago and Johanna de Leeuw, shared a bed behind the basement kitchen. ${ }^{86}$ Similarly, a glance at

86 See Phillips, Well-Being, 47, 213 n. 2. 
the 1617 inventory of the house of Emmanuel Ximenez in Antwerp confirms the radically different living conditions of mistress and maid. ${ }^{87}$

Dutch doll houses display the wealth of their patrons through the abundance and diversity of their furnishings, but in doing so they open a window through which to better understand the lived experience of domestic workers. Although genre paintings and portraits generally show servants performing relatively easy tasks, such as sweeping floors, pouring water for washing, or serving food (Figs. 7.2, 7.6, 7.8, 7.12, 7.18), the cleaning utensils in doll houses make clear that much of what servants did was back-breaking labor: scrubbing pots, pans, and floors, and carrying heavy buckets of water up and down stairs (Fig. 7.16). This is hard for many of us to imagine today with our dishwashers, washing machines, elevators, and vacuum cleaners. A female artist, Geertruyd Roghman, produced a rare suggestion of this grueling work in a print showing a woman with rolled-up sleeves bending low as she scours a platter (Fig. 7.17). Shining in the foreground is the fruit of her labor, the gleaming metal of clean pots. ${ }^{88}$

The objects in doll houses also make clear how skillful early modern servants were. They remind us of tools and practices that have long been forgotten. The lying-in room of Petronella de la Court's house includes tiny sticks that served to smooth bed linens. ${ }^{89}$ Stored in the Dunois cellar are miniature syringes used to clean the exterior of upper story windows. ${ }^{90} \mathrm{~A}$ servant in the de la Court house carries a basket of cleaning tools that include a duster made of a bird's wing, probably used on delicate fabrics. ${ }^{91}$

Doll houses are also stocked with a wide variety of ordinary cleaning utensils, each serving a distinct function: indoor and outdoor brooms, and long- and short-handled scrubbing brushes, mops, brooms, and dusters (Fig. 7.16).$^{92}$ Doll houses, together with contemporary drawings and prints, like the brushseller's stall by Jan Luyken, make clear the different types of cleaning tools, each with its own distinctive handle, shape, size, and type of bristle, according to its function. ${ }^{93}$ Inventories, such as that of the Ximenez home, confirm how

87 For the inventory, which is translated and annotated by Sarah Joan Moran, see http:// ximenez.unibe.ch/inventory/reading/ accessed 2/25/17.

88 For this print series on female occupations, see Martha Moffitt Peacock, "Geertruydt Roghman and the Female Perspective in 17th-Century Dutch Genre Imagery," Woman's Art Journal 14 (1993-1994): 3-10.

$89 \quad$ King, The Collector's History of Doll Houses, 110.

9o Pijzel-Dommisse, The 17th-century Dolls'Houses, 42.

91 Pijzel-Dommisse, Het Hollandse pronkpoppenhuis. 169.

92 Pijzel-Dommissee, The 17th-century Dolls' Houses, 24, 26. One broom is worn down, suggesting that Oortman had used it. See ibid., 26.

93 Luyken's print of a brushseller's stall, dated 1694, is based on his drawing. 


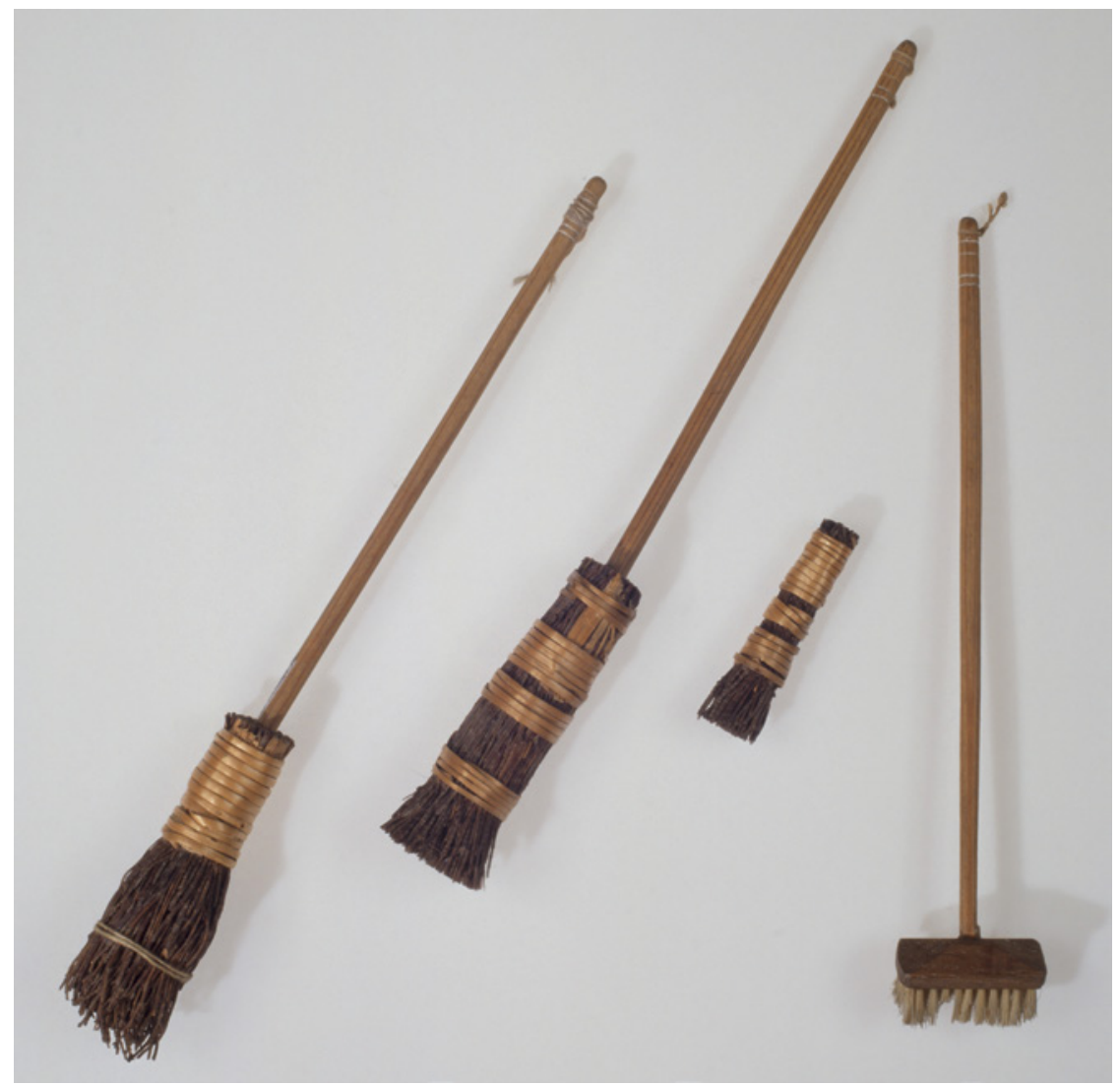

FIGURE 7.16 Scrubbing brushes and street brooms in the cellar of the dolls' house of

Petronella Oortman, c. 1690-1700, Rijksmuseum, Amsterdam

well-equipped with cooking and cleaning tools wealthy households were. ${ }^{94}$ A glance at the objects in the laundry rooms of doll houses - the irons, brushes, linen presses, wicker baskets, bowls for sprinkling water before ironing, and racks for hanging wet laundry - make clear the skill needed to dry, starch, press, and iron linen and clothing (Fig. 7.13, upper left; Fig. 7.14, upper right).

Other material remains remind us that servants' work was often dirty. Closestools and chamber pots that servants emptied and cleaned are included in these doll houses. ${ }^{95}$ But this sort of work was not portrayed in paintings, and

94 For the Ximenez inventory, see note 86.

95 In the Oortman doll house, the toilet is in the back of the kitchen and in the Dunois doll house, it is in the upper peat loft. See Pijzel-Dommisse, The 17th-century Dolls' Houses, 24, 32; King, The Collector's History of Doll Houses, 120. 


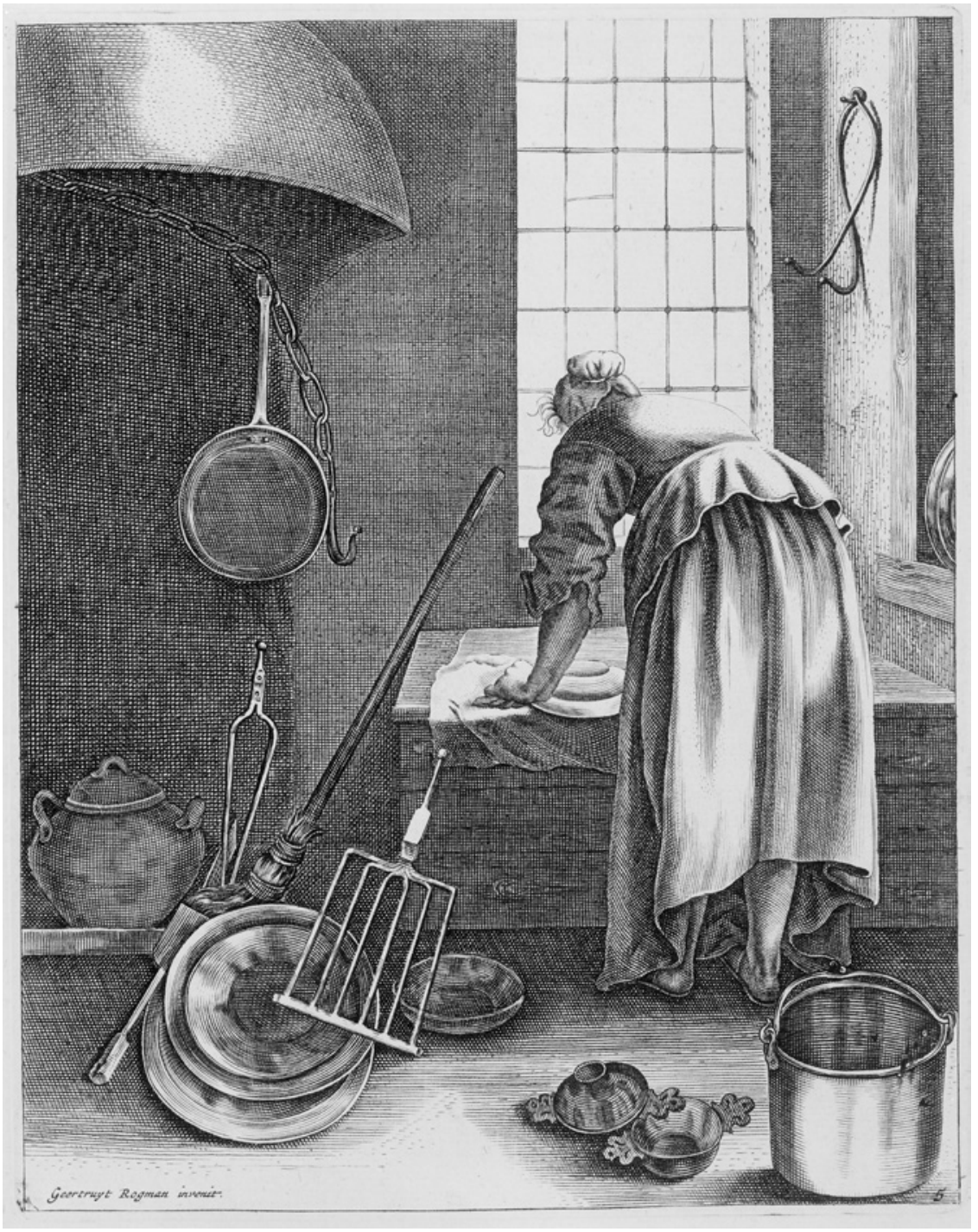

FIGURE 7.17 Geertruyd Roghman, "The Scouring Woman," Plate 5 from Female Activities, c. 1648-5o(?), Metropolitan Museum of Art, New York

even in doll houses such objects are hidden from view. ${ }^{96}$ It may have been servants' contact with such base materials as dirt and excrement that sometimes

96 The doll houses include several servants, which would have been true of only the very wealthiest Dutch homes. The laundresses in such homes were probably outside help, hired once a year to do the entire house's linen, judging by the number of baskets in the laundry room. See King, The Collector's History of Doll Houses, 116. 


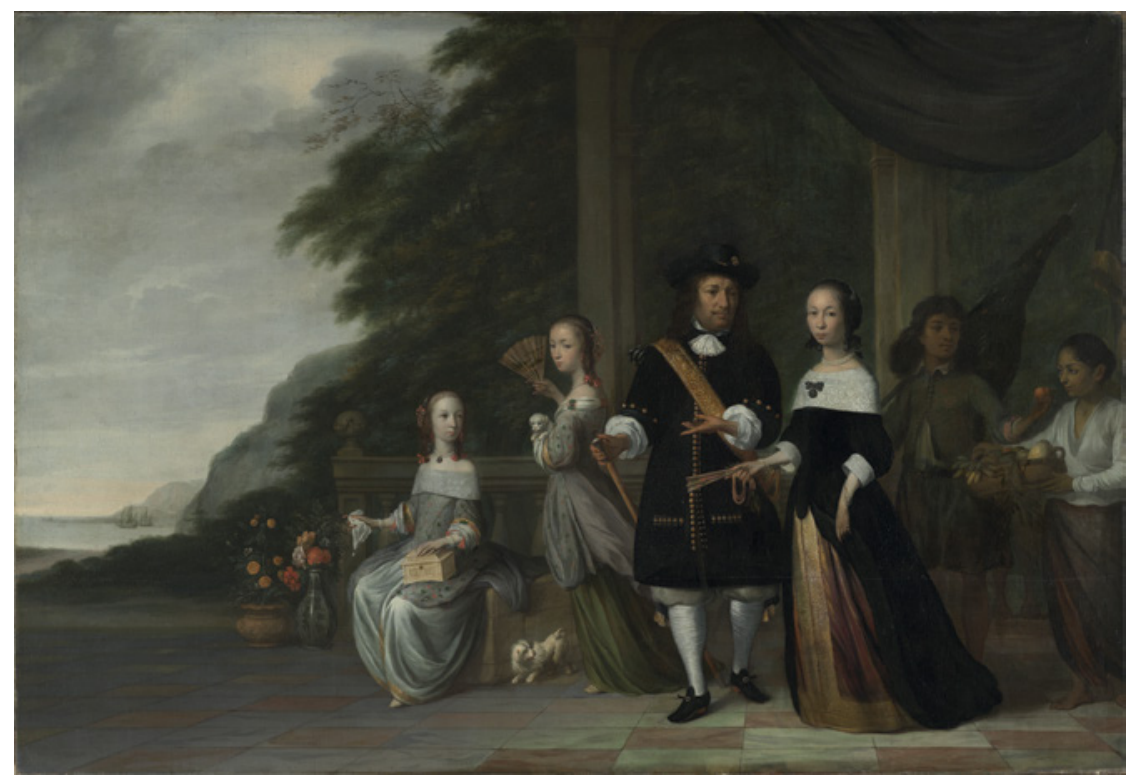

FIGURE 7.18 Jacob Coeman, Pieter Cnoll, Cornelia van Nijenrode and their Daughters, 1665, Rijksmuseum, Amsterdam

led to their master's desire to make servants invisible. The clearest example of such invisibility is seen in Petronella Oortman's doll house. Here the servants' small bedrooms are not only relegated to the rear of the attic, but are also only dimly and partially visible through two openings in the back wall of the laundry room. In other words, they are hidden not only from the viewer, but also from the elite dolls in the house, since the only adjacent room is the peat and provisions loft, an area not frequented by the master and mistress. Furthermore, servants' tools - buckets, tubs, cooking pots, coal pans, two brooms, and a long-handled scrubbing brush - are stored out of sight in the cellar of this doll house. To view them one must either open a trap-door in the floor of the ground-floor kitchen or pull out the drawer into which the storage room was built and thereby access a peephole. By the late seventeenth century, in upper class homes one ideal for servants - and any signs of their labor - was invisibility.

Images of servants were transformed from the fifteenth through the seventeenth centuries. Large aristocratic households throughout Europe were characterized 
by vast numbers of servants, mostly white boys and men. ${ }^{97}$ Although few such households existed in seventeenth-century Holland, they flourished in earlier times and other areas. Fifteenth-century Flemish illuminations, mostly made for courtly patrons, usually show those who serve food and drink, pour water for washing, and help their master dress as small male figures. ${ }^{98}$ Boys went into service at a young age, and being a servant was sometimes a temporary, early stage in life, but servants are portrayed as short in stature even when they are clearly represented as adults, such as in the Flemish Spinola Hours, a Dutch prayer book (where the servant is bald), and the Netherlandish Croesinck Hours (where the servant is bearded) (Fig. 7.19). ${ }^{99}$

In these images sometimes class trumps gender. In a Wedding Feast at Cana from the Flemish Très Belles Heures, male servants are shown as subservient to women (Fig. 7.20). Whereas the bride wears a full-length dress, sits at center stage and is the only figure to face frontally, the male servant on the left wears a short tunic, is seen from the rear, off to the side, and kneels deferentially before her. ${ }^{100}$ What does it say about the relative importance of gender and class that male servants are not only portrayed like their female counterparts - that is off to the side, seen from the back, overlapped by other figures or architecture, and cut off by the frame - but also smaller than and subservient to elite women? This confirms the idea that fifteenth-century servants in aristocratic courts were viewed as not quite men, but rather, even if an adult, still in many ways like a boy or a low-status woman. Indeed some contemporary documents make clear that male servants were considered dependents and treated much like serving women. Yet there is one way in which male servants are differentiated from female ones in early Netherlandish art made for the court: they

97 Diane Wolfthal, "When Did Servants become Men?" in Rivalrous Masculinities, ed. Ann Marie Rasmussen and J. Christian Straubhaar (Notre Dame, IN: University of Notre Dame Press, in press).

98 See Wolfthal, "When Did Servants become Men?".

99 For Jeremy Goldberg, "Girls Growing Up in Later Medieval England," History Today, 45 (1995): 29, being a servant was a stage in life. C. M. agrees states that late-medieval English household servants were "overwhelmingly young." Derek G. Neal, The Masculine Self in Late Medieval England (Chicago: University of Chicago Press, 2008), 14-15, asserts that they were "usually in their teens and twenties," and that usually being a servant was a temporary stage. See Netherlands, "Pontius Pilate Washing his Hands," New York, Morgan Library, Croesinck Hours, MS. M.1078, fol. 44v, detail, ca. 1494, and North Netherlands, "Pontius Pilate Washing his Hands," The Hague, KB, Prayer Book, 135 E 19, fol. $78 \mathrm{v}$, historiated initial. Even today a waiter may be called garçon. See Sarti, "Who are Servants?," 6.

100 For this image, see François Boespflug and Eberhard König, Les très belles heures de Jean de France, duc de Berry (Paris: Cerf, 1998), 28. 


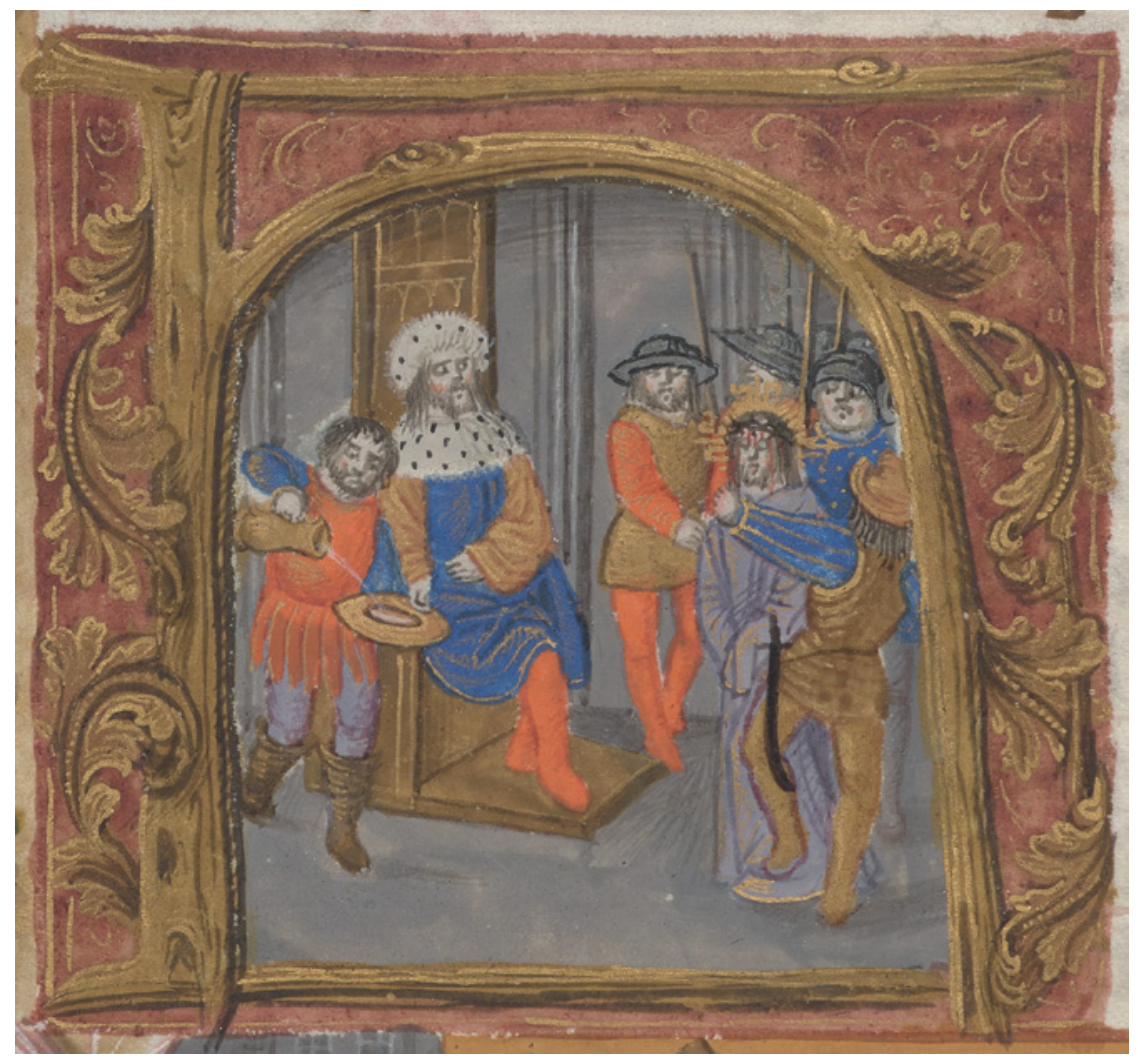

FIGURE 7.19 Anon. (Netherlandish school), Pontius Pilate Washing his Hands, detail, Croesinck Hours, c. 1494, MS. M.1078, fol. 44v, Morgan Library, New York

generally perform different tasks. In fifteenth- and early sixteenth-century images, women are generally shown serving other women, especially as travel companions or aides during and after childbirth. ${ }^{101}$ Fifteenth-century Flemish art was often made for merchants and panel paintings of religious narratives are frequently are set in mercantile, rather than courtly, homes. Yet they rarely include female servants; it is only in later art that female servants become dominant. ${ }^{102}$

101 C. M. Woolgar, The Great Household in Late Medieval England (New Haven and London: Yale University Press, 1999) 34, reports that in late-medieval England the few women and girls who were employed as household servants assisted the ladies of the house.

102 The shift from large numbers of mostly male servants for aristocratic household to one or two female servants in bourgeois homes is traceable by the sixteenth century. See, among others, Carlson, "A Trojan horse of worldliness," 88 and n. 7. Phillips, Well-being, 73, concludes that domestic workers were the largest group of wage-earners in seventeenthcentury Amsterdam and that more than $95 \%$ of Dutch servants were women. 


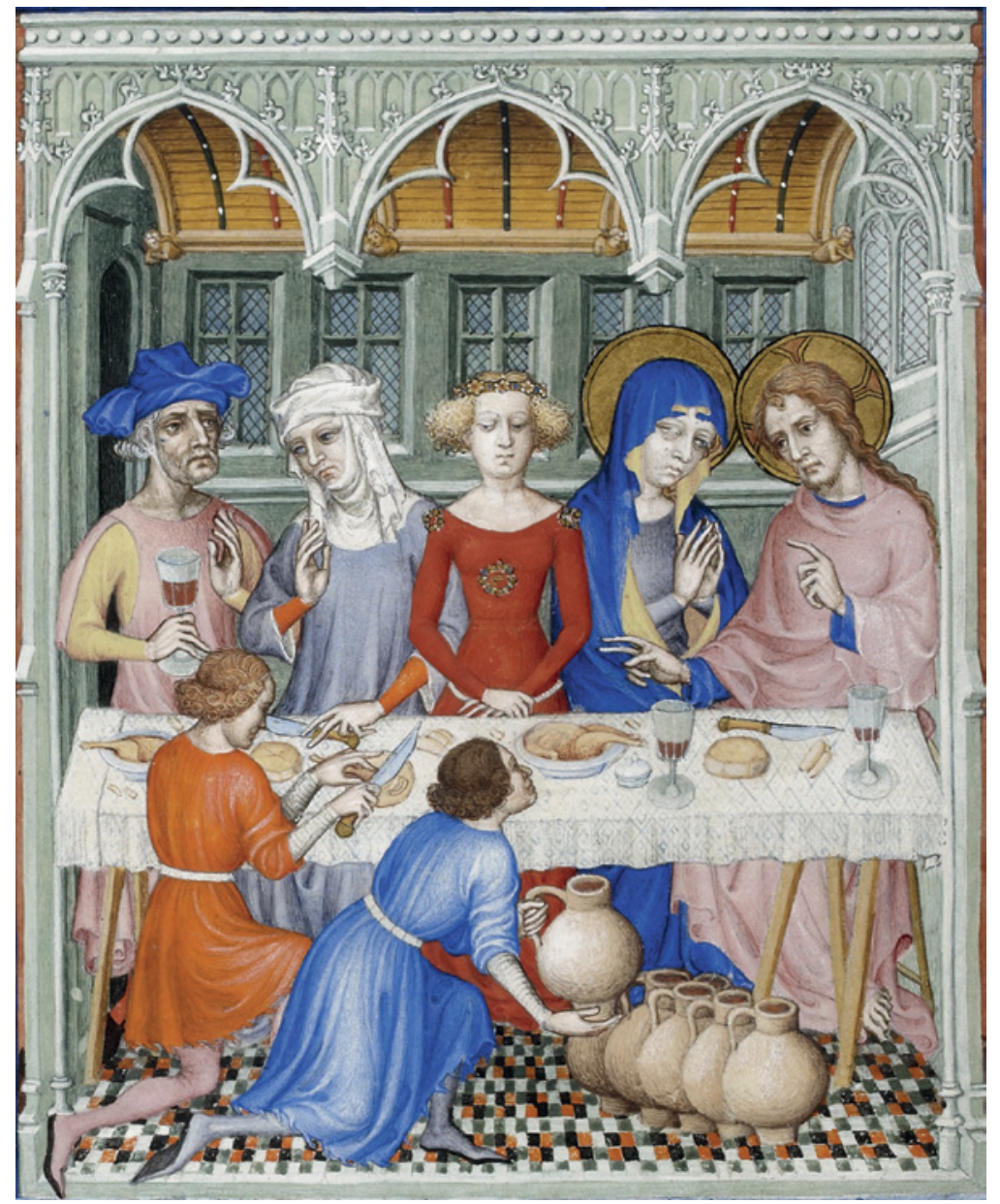

FIgure 7.20 Anon., Miracle at the Marriage at Cana, from the Très Belles

Heures de Notre-Dame, c. 1380 , Ms. nouv. acq. lat. 3903, fol. $67 \mathrm{v}$, Bibliothèque nationale de France, Paris

By the seventeenth century, with the rise of global trade and colonial power, men and women, boys and girls, and those of European, African, and Asian descent are all represented working in the home, and those servants who perform the same duties are often portrayed in a similar way regardless of race and gender. For example, in a drawing by Jacob Jordaens, a black man and a white woman work together in the kitchen (Fig. 7.21).

No hierarchy is visible as they work harmoniously together, their bodies bending towards each other much like the two parts of a parenthesis. Similarly, images of servants offering fruit include a black youth in one portrait, a white youth in another, a white woman in Jordaens' portrait, a black woman in a 


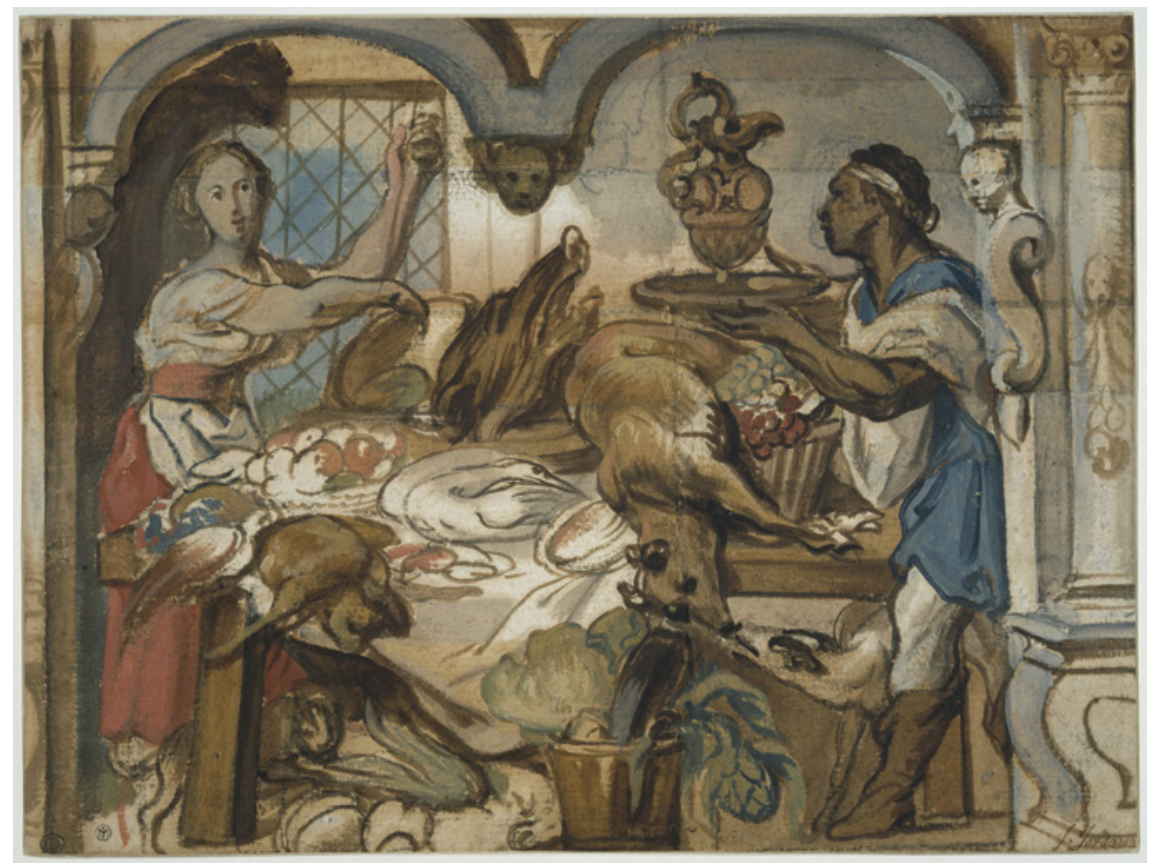

FIG URE 7.21 Jacob Jordaens, Kitchen Scene, seventeenth century, École nationale supérieure des Beaux-Arts, Paris

still life, and an Indonesian woman in a portrait of a Batavian merchant and his family (Figs. 7.8, 7.18). ${ }^{103}$ To cite one last example, both white and black women help their mistress at her toilette (Figs. 7.1, 7.2). If the category of ordinary servant as portrayed in seventeenth-century Netherlandish art was quite diverse, it generally excludes one group: white men. This distinction is made clear in the portrait by van der Helst (Fig. 7.6); here of the three servers, it is the white male who is differentiated through his commanding gesture and more foreground and central position.

In short, over the course of the fifteenth through seventeenth centuries, Netherlandish images show a change in the way ordinary household servants are depicted, from predominantly white males, even if small in stature, to anything but white men. Similar distinctions between elite men and everybody

103 Julie Berger Hochstrasses, Still Life and Trade in the Dutch Golden Age (London and New Haven: Yale University Press, 2007), 208, fig. 229; 213, fig. 123. For the Batavian portrait, which includes two slaves, see Harm Stevens, "Batavian Senior Merchant Pieter Cnoll, His Eurasian Wife and Daughters and Domestic Slaves," in Kees Zandvliet, The Dutch Encounter with Asia, 1600-1950 (Amsterdam: Rijksmuseum and Zwolle: Waanders, 2003), 200-202. 
else are found elsewhere in European culture. To cite just one example, early modern Yiddish books repeat the topos that they have been written for women and "men who are like women," that is, those not learned in the holy tongue. As Jerold Frakes observes, "This is a typical ideological move in attempts to debase a language of whatever kind: by relegating it to inferior status within the culture by assigning it to use by members of an inferior group which is by definition also inferior - in this, as in so many cases, women." 104 Netherlandish artists generally marginalized servants, buried them in the shadows, sometimes even dehumanized them. Yet the images discussed here reveal a wide range of reasons why they were represented: to portray the proper management of the home or the high status of the household, to serve as a negative foil for their master or mistress, to reinforce proper class distinctions, and, on rare occasions, to express affection for domestic workers. If we move beyond genre paintings and prints to examine such long-neglected sources as biographies of artists' lives, portraits of domestic workers, and doll houses, we can better understand that servants' work was grueling, dirty, and skilled, and that the gender and race of domestic servants was transformed as global trade and colonial empires expanded. By turning to sources other than Golden Age paintings and prints, we can foreground figures who for too long have been relegated to the background.

104 Jerold C. Frakes, The Politics of Interpretation: Alterity and Ideology in Old Yiddish Studies (Albany: State University Press of New York, 1989), 16. 